\title{
Burial-nutrient feedbacks amplify the sensitivity of atmospheric carbon dioxide to changes in organic matter remineralisation
}

\author{
R. Roth ${ }^{1,2}$, S. P. Ritz ${ }^{1,2}$, and F. Joos ${ }^{1,2}$ \\ ${ }^{1}$ Climate and Environmental Physics, Physics Institute, University of Bern, Bern, Switzerland \\ ${ }^{2}$ Oeschger Centre for Climate Change Research, University of Bern, Bern, Switzerland
}

Correspondence to: R. Roth (roth@climate.unibe.ch)

Received: 28 March 2014 - Published in Earth Syst. Dynam. Discuss.: 14 April 2014

Revised: 19 August 2014 - Accepted: 28 August 2014 - Published: 16 October 2014

\begin{abstract}
Changes in the marine remineralisation of particulate organic matter (POM) and calcium carbonate potentially provide a positive feedback with atmospheric $\mathrm{CO}_{2}$ and climate change. The responses to changes in remineralisation length scales are systematically mapped with the Bern3D ocean-sediment model for atmospheric $\mathrm{CO}_{2}$ and tracer fields for which observations and palaeoproxies exist. Results show that the "sediment burial-nutrient feedback" amplifies the response in atmospheric $\mathrm{CO}_{2}$ by a factor of four to seven. A transient imbalance between the weathering flux and the burial of organic matter and calcium carbonate lead to sustained changes in the ocean's phosphate and alkalinity inventory and in turn in surface nutrient availability, marine productivity, and atmospheric $\mathrm{CO}_{2}$. It takes decades to centuries to reorganise tracers and fluxes within the ocean, many millennia to approach equilibrium for burial fluxes, while $\delta^{13} \mathrm{C}$ signatures are still changing 200000 years after the perturbation. At $1.7 \mathrm{ppm} \mathrm{m}^{-1}$, atmospheric $\mathrm{CO}_{2}$ sensitivity is about fifty times larger for a unit change in the remineralisation depth of POM than of calcium carbonate. The results highlight the role of organic matter burial in atmospheric $\mathrm{CO}_{2}$ and the substantial impacts of seemingly small changes in POM remineralisation.
\end{abstract}

\section{Introduction}

The mixing ratio of $\mathrm{CO}_{2}$ in the atmosphere varied by $\sim 80$ 100 parts per million (ppm) in past glacial-interglacial cycles on timescales of $\sim 100$ thousand years (kyr) (Petit et al., 1999; Siegenthaler et al., 2005; Lüthi et al., 2008). Biogeochemical processes leading to their variations are still poorly quantified (see reviews by Sigman and Boyle, 2000; Archer et al., 2000; Sigman et al., 2010; Fischer et al., 2010), especially the slowly acting mechanisms. Several hypotheses have been discussed to explain the $\mathrm{CO}_{2}$ drawdown leading to the Last Glacial Maximum (LGM). These include ocean circulation and stratification changes (Siegenthaler and Wenk, 1984; Watson and Garabato, 2006; Bouttes et al., 2010; Völker and Köhler, 2013), continental weathering (Munhoven, 2002), volcanism (Huybers and Langmuir, 2009; Roth and Joos, 2012), changes in the ocean's biological pump, e.g. by changes in its strength as modulated by the availability of micro- and macro-nutrients (Parekh et al., 2008; Tschumi et al., 2011; Oka et al., 2011), or changes in the export rain ratio (Matsumoto et al., 2007; Tschumi et al., 2011).

Changes in the remineralisation of particulate organic matter (POM) have recently been suggested as a further feedback which may contribute considerably to past and future $\mathrm{CO}_{2}$ changes. How POM is converted to inorganic nutrients in the water column depends on the speed with which the particles sink towards the ocean floor and on the local rate of remineralisation. An increase in temperature is expected to promote bacterial activities and to increase local remineralisation rate (Bendtsen et al., 2002), and to decrease viscosity and thus increase the speed of sinking particles (Taucher et al., 2014). In addition, changes in ecosystem structure in the surface ocean potentially affect the size and density distribution of the settling particles and thus sinking speed (Armstrong et al., 2002, 2009). In short, such changes in the 
organic matter cycle influence the surface-to-deep transport of nutrients and carbon and thus respired carbon storage in the deep ocean. A deepening of the remineralisation depth of POM - corresponding to a lower rate of degradation as e.g. induced by lower bacterial activity - results in a drawdown of atmospheric $\mathrm{CO}_{2}$.

The mechanism of a deepening of the POM remineralisation has been discussed and quantified in several studies. Matsumoto (2007) estimated a $\mathrm{CO}_{2}$ drawdown of $\sim 35 \mathrm{ppm}$ for a $5{ }^{\circ} \mathrm{C}$ ocean cooling experiment and using a threedimensional ocean model. On the other hand, Chikamoto et al. (2012) finds only a small $\mathrm{CO}_{2}$ sensitivity to a $5{ }^{\circ} \mathrm{C}$ ocean cooling ( $-9 \mathrm{ppm})$. Kwon et al. (2009) simulate a $\mathrm{CO}_{2}$ drawdown by 10 and $27 \mathrm{ppm}$ for an increase in the e-folding depth of POM remineralisation of $24 \mathrm{~m}$ in their nutrientrestoring and constant export-production model setups. Recently, Segschneider and Bendtsen (2013) estimated a reduction of anthropogenic $\mathrm{CO}_{2}$ uptake rates of 0.2 gigatons of carbon $(\mathrm{GtC})$ per year by AD 2100 in future emission scenarios. Taucher et al. (2014) isolate the influence of viscosity changes in a global warming simulation and found that ocean carbon uptake is $17 \%$ higher when considering temperaturedriven viscosity changes on particle sinking speed compared to a control. As a caveat, these studies either focus on the decadal- to century-scale response (Segschneider and Bendtsen, 2013) or neglect ocean-sediment interactions and the weathering-burial cycle.

Ocean-sediment interactions (including weathering and burial) can amplify or mitigate a perturbation in the oceanatmosphere system. For example, excess anthropogenic carbon is ultimately removed from the ocean-atmosphere system by calcium carbonate $\left(\mathrm{CaCO}_{3}\right)$ sediment buffering and burial. On the other hand, the change in atmospheric $\mathrm{CO}_{2}$ in response to a change in calcite export is about four times larger in an "open" system considering sediment interactions as compared to a "closed" ocean-atmosphere system (e.g. Tschumi et al., 2011). Concenrning the role of the organic matter cycle, Tschumi et al. (2011) identified the importance of the nutrient-burial feedback for a range of mechanisms with the potential to explain low glacial $\mathrm{CO}_{2}$. They conclude that the long-term balance between burial of organic material and tracer input into the ocean through weathering, typically neglected in earlier studies, must be considered when investigating the glacial-interglacial evolution of atmospheric $\mathrm{CO}_{2}$ and related tracers. However, these authors did not investigate changes in the remineralisation depth of POM.

As the mean remineralisation depth of POM is altered, the deposition of POM on the seafloor and burial rates are also expected to change. This leads to a transient imbalance between burial and continental weathering fluxes on multimillennial timescales. The consequences of these imbalances have not been discussed so far in a systematic manner and in the context of a three-dimensional, dynamic model. Matsumoto et al. (2007) discuss the effect of altered temperature on export and remineralisation rate. They applied an ecosys- tem model embedded in a dynamic ocean model and simulate a change in the export rain ratio between particulate organic carbon and $\mathrm{CaCO}_{3}$ in response to altered temperatures. They argue that the effect of temperature on POM degradation has a more dominant impact on the export rain ratio than on POM remineralisation depth scale. Accordingly, only the change in rain ratio is prescribed in a box-type oceansediment model to estimate changes in atmospheric $\mathrm{CO}_{2}$, but the impact of a deepening of the remineralisation depth as well as changes in the burial of organic matter are neglected by Matsumoto and colleagues. Menviel et al. (2012) performed transient model simulations over the last glacial cycle with the Bern3D model applying a temperature-dependent remineralisation rate. They simulated a $31 \mathrm{ppm}$ decrease in atmospheric $\mathrm{CO}_{2}$ for a progressive increase of the POM and DOM remineralisation depth over the glaciation, while $\mathrm{CO}_{2}$ increased by $21 \mathrm{ppm}$ due to altered remineralisation over the deglaciation. This suggests that ocean-sediment interactions may contribute to the reconstructed atmospheric $\mathrm{CO}_{2}$ variations, motivating the present study.

The goals of this study are to map systematically the spatio-temporal response to alterations in the remineralisation depth in a three-dimensional, dynamic model setting. The response in carbon isotopes, nutrients as well as in atmospheric $\mathrm{CO}_{2}$ and its carbon isotopic signatures are analysed. A series of well-defined sensitivity experiments is performed, where the POM remineralisation depth is changed in a step-like manner. The Bern3D dynamic ocean model of intermediate complexity is applied with prognostic formulations of export production coupled to a three-dimensional sediment component, allowing for the quantification of the long-term sediment feedback associated with both POM and $\mathrm{CaCO}_{3}$ burial on marine chemistry and atmospheric $\mathrm{CO}_{2}$ and ${ }^{13} \mathrm{CO}_{2}$. In addition, changes in the calcite dissolution rate are considered. We show that previous estimates of the sensitivity of POM remineralisation rate changes are not applicable on glacial-interglacial timescales, as they do not include the long-term feedback, but point to a potential importance of this mechanism to explain low-frequency $\mathrm{CO}_{2}$ and ${ }^{13} \mathrm{CO}_{2}$ variations. The nutrient-burial feedback (Tschumi et al., 2011) amplifies the initial response to a deepening of the POM remineralisation by a factor of between 3 and 7 in our model.

\section{Model}

\subsection{Physical model}

We invoke an updated (see Appendix) version of the Bern3D Earth system model of intermediate complexity (EMIC). Its frictional geostrophic balance three-dimensional ocean component is based on the model of Edwards and Marsh (2005) and is further improved as described in Müller et al. (2006). It includes an isopycnal diffusion scheme and Gent-McWilliams parameterisation for eddy-induced 

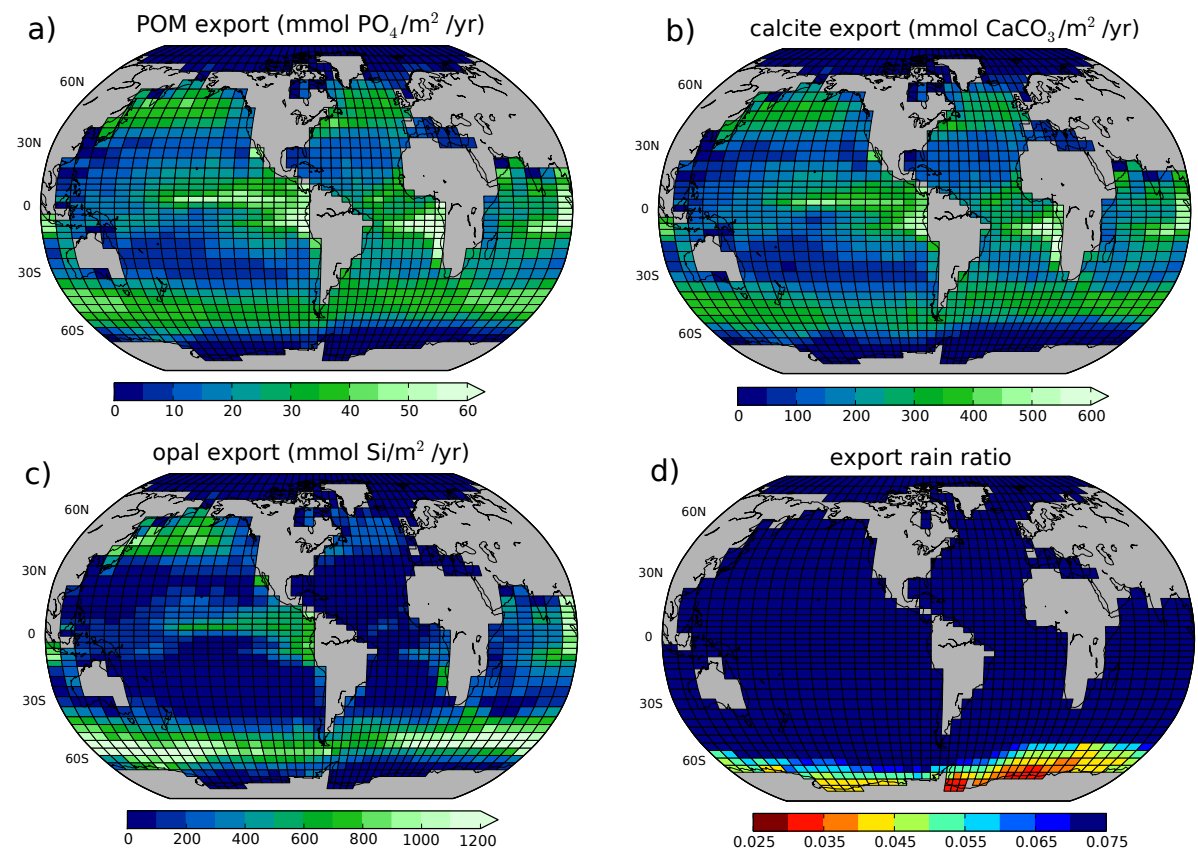

Figure 1. Preindustrial, annual mean distribution of (a) POM export, (b) calcite export, (c) opal export. The ratio of inorganic to organic carbon export (rain ratio) is shown in (d).

transport (Griffies, 1998). The horizontal resolution is now set to $41 \times 40$ grid boxes in the horizontal, while $32 \log$ arithmically spaced layers in the vertical are used. Wind stress is prescribed according to the monthly climatology from NCEP/NCAR (Kalnay et al., 1996). The atmosphere is represented by a two-dimensional energy and moisture balance model (EBM) with the same horizontal resolution as the ocean described in Ritz et al. (2011a). Following Weaver et al. (2001), outgoing longwave radiative fluxes are parameterised after Thompson and Warren (1982) with additional radiative forcings due to e.g. $\mathrm{CO}_{2}$, other greenhouse gases and volcanic aerosols. The sea-ice model component is based on work by Semtner (1976) and Hibler (1979), and is similar to the sea-ice model of Edwards and Marsh (2005).

Air-sea gas exchange for $\mathrm{CO}_{2}$ and ${ }^{14} \mathrm{CO}_{2}$ is implemented according to the OCMIP-2 protocol (Orr and Najjar, 1999; Najjar et al., 1999), but with a reduced scaling factor (Müller et al., 2008). ${ }^{14} \mathrm{CO}_{2}$ is not fractionated during air-sea gas exchange, while ${ }^{13} \mathrm{CO}_{2}$ is fractionated as a function of temperature and carbonate chemistry, as detailed in Müller et al. (2008).

\subsection{The marine biogeochemical cycle and particle remineralisation}

The marine biogeochemical module computes the cycling of carbon (C), alkalinity (Alk), phosphate $\left(\mathrm{PO}_{4}\right)$, iron (Fe), oxygen $\left(\mathrm{O}_{2}\right)$, silica $\left(\mathrm{SiO}_{2}\right)$, and the carbon isotopes ${ }^{13} \mathrm{C}$ and ${ }^{14} \mathrm{C}$. Carbon is represented as dissolved inorganic carbon (DIC) and labile dissolved organic carbon (DOC).
Prognostic formulations link marine productivity and dissolved organic matter (DOM) to available nutrients $\left(\mathrm{PO}_{4}\right.$, $\mathrm{Fe}, \mathrm{SiO}_{2}$ ), temperature, sea ice and light using MichaelisMenten limiting terms (Doney et al., 2006) in the euphotic zone (uppermost $75 \mathrm{~m}$ ), as described in Parekh et al. (2008) and Tschumi et al. (2011). POM is exported from the euphotic zone as a constant fraction $(\sigma)$ of new production $\left(\Gamma_{\text {new }}\right)$ at the reference depth $z_{0}$. The remainder (i.e. $\left.1-\sigma\right)$ is transferred to the labile DOM pool. The export between $\mathrm{CaCO}_{3}$ and particulate organic carbon (POC) - i.e. the export "rain ratio" - is constant $(\sim 0.075)$ unless silicic acid is abundant; in this case diatom growth is favoured at the expense of calcifier growth. The rain ratio is therefore lowered in these $\mathrm{SiO}_{2}$-replete regions, which is primarily the case in the Southern Ocean upwelling regions (south of $\sim 60^{\circ} \mathrm{S}$; Fig. 1).

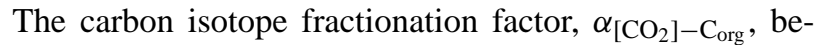
tween dissolved $\mathrm{CO}_{2}$ and organic carbon, depends on the concentration of dissolved $\mathrm{CO}_{2}\left(\left[\mathrm{CO}_{2}\right]\right)$ in units of $\mu \mathrm{mol} \mathrm{kg}{ }^{-1}$ according to Freeman and Hayes (1992):

$$
\begin{aligned}
\alpha_{\mathrm{CO}_{2}-\mathrm{C}_{\text {org }}} & =\frac{{ }^{13} \mathrm{R}\left(\left[\mathrm{CO}_{2}\right]\right)}{{ }^{13} \mathrm{R}\left(C_{\text {org }}\right)} \\
& =1.00119+0.01203 \cdot \log \left[\mathrm{CO}_{2}\right] .
\end{aligned}
$$

This results in an isotopic signature of POC of around $-20 \%$. Important in our context (see Sect. 3.1.3), a lowering of $\left[\mathrm{CO}_{2}\right]$, or correspondingly of $p \mathrm{CO}_{2}$, by $10 \%$ yields a change in the isotopic signature of POC by $+0.55 \%$. 

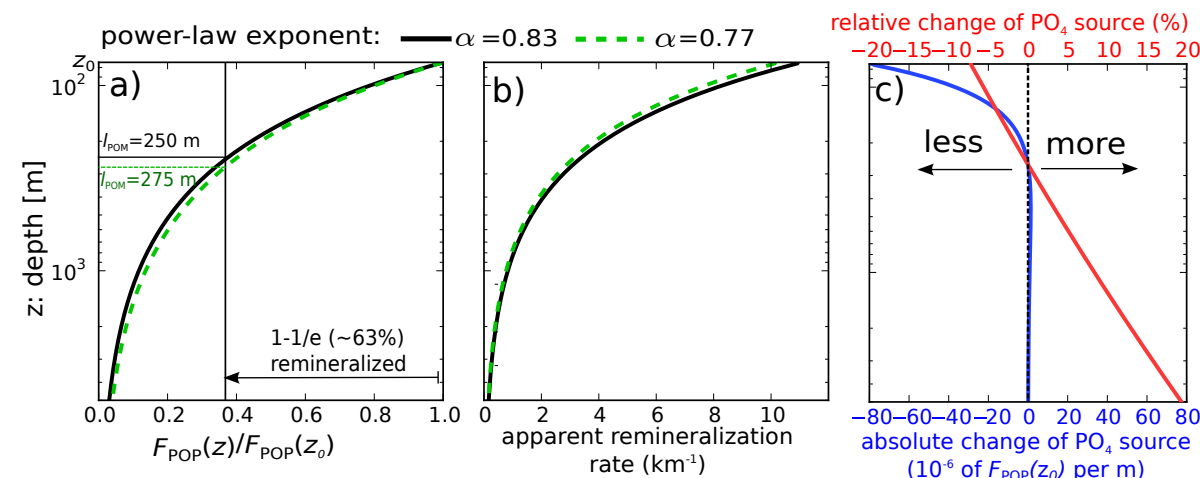

Figure 2. (a) Parametrisation of the particulate organic matter flux within the water column (expressed here in terms of POP) out of the euphotic zone $\left(z_{0}=75 \mathrm{~m}\right)$ according to a power law $F(z)=F\left(z_{0}\right) \cdot\left(z / z_{0}\right)^{-\alpha}$, with $\alpha=0.83$ being the base case (black line). The depth is positive downwards (note the logarithmic scaling). (b) The apparent rate of remineralisation $(k / v)$, i.e. $-(\mathrm{d} F(z) / \mathrm{d} z) / F(z)$. The green line represents the corresponding values for a hypothetical deepening of the POM remineralisation $(\alpha=0.83 \rightarrow 0.77$, or expressed as a change in the e-folding depth $l_{\mathrm{POM}}, 250 \mathrm{~m} \rightarrow 275 \mathrm{~m}$ ). Such a change leads to a decrease in the upper ocean $\mathrm{PO}_{4}$ source, while the deep ocean (below $\sim 250 \mathrm{~m}$ ) is enriched in $\mathrm{PO}_{4}$, as depicted in (c).

DOM remineralisation is implemented using a fixed decay time of $0.5 \mathrm{yr}$. The remineralisation of sinking POM results from the prescribed depth-dependent scaling of the flux of particulate organic phosphorus (POP) and POM (Fig. 2), known as the "Martin curve" (Martin et al., 1987):

$F_{\mathrm{POP}}(z)=F_{\mathrm{POP}}\left(z_{0}\right) \cdot\left(\frac{z}{z_{0}}\right)^{-\alpha}$ for $z>z_{0}$.

Here, $F_{\mathrm{POP}}(z)$ is the downward flux of POP at depth $z$ ( $z$ positive downwards) and $F_{\mathrm{POP}}\left(z_{0}\right)$ the POP flux at the reference depth $z_{0}=75 \mathrm{~m}$. Other elements such as carbon, carbon isotopes, oxygen and alkalinity are coupled to POP and DOP by constant elemental (Redfield) ratios set to $\mathrm{P}: \mathrm{C}:$ Alk: $\mathrm{O}_{2}=1: 117:-17:-170$. The exponent $\alpha$ defines the shape of the curve: a high value of $\alpha$ shoals while a low $\alpha$ deepens the depth at which organic matter is remineralised. $\alpha$ is set to a globally uniform value of 0.83 in the standard setup.

The empirical relationship of Eq. (2) - a result of a fit through sediment-trap data - makes per se no statement on the rate of remineralisation, as both sinking speed and degradation contribute to the vertical profile of observed POM concentrations. The remineralisation of POP, $R$, can be written as

$R(z)=k \cdot[\mathrm{POP}]=k / \bar{v} \cdot F_{\mathrm{POP}}(z)=\mathrm{d} F(z) / \mathrm{d} z$.

$k$ is the remineralisation rate coefficient in $\mathrm{s}^{-1},[\mathrm{POP}]$ the concentration of POP in the water, and $\bar{v}$ the mean sinking speed of POP. It follows, by rearranging Eq. (3), and with the help of Eq. (2), for the apparent rate of remineralisation, $k_{\text {app }}$ (in units of $\mathrm{m}^{-1}$ ), that

$k_{\mathrm{app}}=k / \bar{v}=\frac{1}{F_{\mathrm{POP}}(z)} \cdot \mathrm{d} F_{\mathrm{POP}}(z) / \mathrm{d} z=-\alpha\left(\frac{z_{0}}{z}\right)^{-1}$.
The apparent remineralisation rate $(k / \bar{v})$ decreases inversely proportional to depth $z$ (Fig. $2 b$ ). Although the POM degradation rate is not constant over depth, we define an efolding depth as a length scale $\left(l_{\mathrm{POM}}\right)$ for convenience; that is, the depth at which the downward POM flux has diminished to $1 / e \approx 37 \%$ is

$F_{\mathrm{POP}}\left(z=l_{\mathrm{POM}}\right) / F_{\mathrm{POP}}\left(z_{0}\right)=(1 / e) \rightarrow l_{\mathrm{POM}}=z_{0} \cdot e^{1 / \alpha}$.

$l_{\mathrm{POM}}$ is $250 \mathrm{~m}$ for the standard value of $\alpha=0.83$. The flux of organic matter is sketched in Fig. 2. The downward flux of calcite (including other forms of calcium carbonate such as aragonite or high-magnesium calcite particles) $\left(F_{\text {calc }}\right)$ decreases exponentially with depth with a length scale $l_{\text {calc }}$ :

$F_{\text {calc }}(z)=F_{\text {calc }}\left(z_{0}\right) \cdot e^{-\frac{z-z_{0}}{l_{\text {calc }}}}$ for $z>z_{0}$.

A 10-layer sediment diagenesis model (Heinze et al., 1999; Gehlen et al., 2006) is coupled at the ocean floor. It features the same horizontal resolution as the ocean model. It dynamically calculates the transport, remineralisation/redissolution and bioturbation of solid material within the top $10 \mathrm{~cm}$ of the seafloor as well as pore-water chemistry and diffusion as described in detail in Tschumi et al. (2011). Modelled tracers are the four solid components $\left(\mathrm{CaCO}_{3}\right.$, opal, POM and clay) and the eight pore water substances (DIC, DIC-13, DIC-14, total alkalinity, phosphate, nitrate, oxygen and silicic acid). The pore water $\mathrm{CO}_{3}^{2-}$ concentration determines whether, and at which rate, $\mathrm{CaCO}_{3}$ dissolves. The inclusion of the dissolution and burial process of $\mathrm{CaCO}_{3}$ is crucial for simulating the so-called carbonate compensation.

The oxidation rate of POM within the diagenetic zone depends linearly on the porewater concentration of $\mathrm{O}_{2}$ and the weight fraction of POM within the solid phase. Denitrification is not taken into account in this version of the model. The corresponding reaction rate parameters are global 
constants and a decrease in the reactivity of organic material by aging within the diagenetic zone is not considered (Middleburg et al., 1993). Fluxes of carbon and related elements due to POC degradation are coupled by fixed Redfield ratios $\left(\mathrm{P}: \mathrm{N}: \mathrm{C}: \mathrm{O}_{2}=1: 16: 117:-170\right.$ for oxidation). The model assumes conservation of volume, i.e. the entire column of the sediments is pushed downwards if deposition exceeds redissolution into pore waters. In this manuscript, the term "burial" refers to the net tracer flux at the oceansediment interface, i.e. "burial = deposition - redissolution" of the particulate material. The burial efficiency, i.e. the burial/deposition ratio of a solid species, is controlled by (i) the rate of redissolution within the sediments and (ii) by the rain rate of solid species, which controls how fast the sediment column is pushed downwards.

Any solid material that is pushed out of the diagenetic zone (top $10 \mathrm{~cm}$ ) disappears into the subjacent diagenetically consolidated zone. The fate of this material is of no further interest for this study (it is known that preferential degradation of POC versus that of POP and the conversion of POP to oxideassociated $\mathrm{P}$ and authigenic $\mathrm{P}$ within the consolidated zone cause $\mathrm{C}: \mathrm{P}$ ratios of organic material to deviate substantially from the classical Redfield ratio, Anderson et al., 2001). Input of terrestrial organic matter into the ocean and burial of terrestrial organic matter is not explicitly considered. Similarly, the cycling of $\mathrm{P}$ associated with iron and other oxides is neglected, as estimates suggest that $97 \%$ of the P delivered to the sediment-water interface is in the form of organic matter (Delaney, 1998). The specific chemical composition of the organic matter, particle grain size of the sedimentary material and available area for sorption of organic matter (Hedges and Keil, 1995), as well as spatio-temporal variations in mineral deposition rates or sediment porosity, which likely influence organic matter preservation and burial (Burdige, 2007), are neglected.

Here, no land biosphere module is coupled to the Bern3D model, as our interest is in the ocean-atmosphere response to changes in the remineralisation profile of POM and calcite.

\subsection{Model initialisation and preindustrial state}

The model is spun up over $60000 \mathrm{yr}$ to a preindustrial equilibrium corresponding to $\mathrm{AD} 1765$ boundary conditions. $\mathrm{CO}_{2}$ is set to $278 \mathrm{ppm}$ and $\delta^{13} \mathrm{C}$ of $\mathrm{CO}_{2}$ to $-6.3 \%$. This results in an oceanic DIC inventory of $\sim 37400 \mathrm{GtC}$, similar to the $37510 \mathrm{GtC}$ as estimated from the GLODAP (Key et al., 2004) and World Ocean Atlas (Locarnini et al., 2010; Antonov et al., 2010) data sets. The loss of tracers due to burial of particulate matter is compensated during the spin up by a variable weathering so as to conserve oceanic inventories of tracers. After the system equilibrated, the weathering fluxes are kept constant at the rate diagnosed during the end of the spin up. Globally integrated fluxes of POM export, deposition and burial are $11.7,0.63$ and $0.18 \mathrm{Gt} \mathrm{C} \mathrm{yr}^{-1}$ for preindustrial conditions.
Table 1. Overview of globally integrated particle fluxes for a preindustrial control simulation.

\begin{tabular}{|c|c|c|c|}
\hline Variable & Units & Value & Range of estimates \\
\hline \multicolumn{4}{|c|}{ Ocean inventory } \\
\hline DIC & $\mathrm{GtC}$ & 37370 & $37510^{\mathrm{a}}$ \\
\hline \multicolumn{4}{|c|}{ Export } \\
\hline $\mathrm{CaCO}_{3}$ & $\mathrm{GtC} \mathrm{yr}^{-1}$ & 0.872 & $0.8-1.2^{b}$ \\
\hline Opal & $\mathrm{T} \mathrm{mol} \mathrm{Si} \mathrm{yr}^{-1}$ & 101 & $102-178^{b}$ \\
\hline POM & ${\mathrm{GtC} \mathrm{yr}^{-1}}^{-1}$ & 11.7 & $6.5-13.1^{\mathrm{c}}$ \\
\hline \multicolumn{4}{|c|}{ Deposition } \\
\hline $\mathrm{CaCO}_{3}$ & $\mathrm{GtC} \mathrm{yr}^{-1}$ & 0.273 & $0.5^{\mathrm{f}}$ \\
\hline Opal & $\mathrm{T}_{\mathrm{mol} \mathrm{Si} \mathrm{yr}}{ }^{-1}$ & 70.2 & $13-47^{\mathrm{e}}$ \\
\hline POM & $\mathrm{GtC}_{\mathrm{yr}}{ }^{-1}$ & 0.630 & $1.7-3.3^{\mathrm{c}}$ \\
\hline \multicolumn{4}{|c|}{ Burial } \\
\hline $\mathrm{CaCO}_{3}$ & $\mathrm{GtC}_{\mathrm{yr}}{ }^{-1}$ & 0.0916 & $0.10-0.14^{\mathrm{d}}$ \\
\hline Opal & T mol Si yr ${ }^{-1}$ & 2.11 & $5.3-8.9^{\mathrm{e}}$ \\
\hline POM & ${\mathrm{GtC} \mathrm{yr}^{-1}}^{-1}$ & 0.181 & $0.12-0.26^{\mathrm{c}}$ \\
\hline \multicolumn{4}{|c|}{ Ocean tracer weathering-burial fluxes } \\
\hline $\mathrm{PO}_{4}$ & $\mathrm{~T}$ mol Pyr ${ }^{-1}$ & 0.130 & \\
\hline DIC & ${\mathrm{GtC} \mathrm{yr}^{-1}}^{-1}$ & 0.273 & \\
\hline$\delta^{13} \mathrm{C}$ & $\%$ & -12.6 & \\
\hline Alk & Teq $_{\text {yr }}-1$ & 13.1 & \\
\hline Silicate & Tmol Si yr $^{-1}$ & 2.11 & \\
\hline
\end{tabular}

a Based on the GLODAP and WOA09 data sets; ${ }^{b}$ Jin et al. (2006);

${ }^{c}$ Sarmiento and Gruber (2006); ${ }^{\mathrm{d}}$ Feely et al. (2004) (excluding continental shelf areas); ${ }^{\mathrm{e}}$ Tréguer et al. (1995); ${ }^{\mathrm{f}}$ Milliman and Droxler (1996).

The partitioning of POM burial between the deep ocean (>1000 $\mathrm{m}$ water depth) and the continental margin $(<1000 \mathrm{~m}$ water depth) is 70 and $30 \%$, respectively, while observations indicate that $80-90 \%$ of the POM burial is on continental margins. This model bias is likely linked to the coarse horizontal resolution and the simple continental runoff scheme, compromising the representation of nearcoast processes.

Table 1 provides an overview of steady-state export, deposition, burial fluxes of POM, calcite and opal, and of the weathering-burial fluxes of different tracers. The model is able to represent the observation-based distribution of tracers in the ocean interior (Appendix, Fig. A1). Known shortcomings are a too sluggish formation of Antarctic Bottom Water in the Atlantic, and intermediate waters do not penetrate far enough towards the Equator.

Modelled POM and calcite export (Fig. 1a and b) is low in the subtropical gyres as well as in the Arctic and around Antarctica. Generally high export fluxes are found in upwelling regions off Africa and South America, in the northern North Pacific and Atlantic, and in the Southern Ocean between $\sim 40$ and $60^{\circ} \mathrm{S}$. The pattern is comparable to those 
simulated by state-of-the-art Earth system models (ESM) and to observation-based estimates (Schneider et al., 2008; Steinacher et al., 2010). Similarly as in ESMs, there is too much new production in the eastern part of the tropical Indian and too little in the Arabian Sea. Modelled opal export (Fig. 1c) features the well-known belt along $60^{\circ} \mathrm{S}$ and maxima in the tropical eastern Pacific and the northwestern Pacific.

\subsection{Experiments}

Sensitivity experiments are performed where $l_{\mathrm{POM}}$ (or equivalently $\alpha$ ) and/or $l_{\text {calc }}$ (Eq. 6) are changed in a step-wise manner (Fig. 3a). The model is then re-equilibrated for up to $200 \mathrm{kyr}$ (some experiments are only integrated for 50 and $100 \mathrm{kyr}$, respectively) in a prognostic mode where atmospheric $\mathrm{CO}_{2}$ and $\delta^{13} \mathrm{C}$ evolve freely. As weathering fluxes are kept constant in the perturbation experiments, global inventories of tracers in the atmosphere-ocean-sediment system are not conserved (Fig. 3h and i). We refer to this setup as "open system". We also run the system in an atmosphere-oceanonly setup without sediment and no river input and burial, referred to as "closed system". The differences in results between the open and closed systems are the contribution by the sediment and weathering-burial feedbacks.

We performed a range of sensitivity experiments where $l_{\mathrm{POM}}$ is varied between 225 and $375 \mathrm{~m}$. Our discussion mainly focuses, as an illustrative example, on results from experiments where the exponent $\alpha$ is changed from 0.83 to 0.77 , corresponding to a change in $l_{\mathrm{POM}}$ from 250 to $275 \mathrm{~m}$.

We restrict our analysis to idealised changes in in the remineralisation length scale (parameter $\alpha$ and $l_{\mathrm{POM}}$ ) as the link between remineralisation and temperature changes is not well understood. Changes in ecosystem structure in the euphotic zone and corresponding changes in the quality and sinking speed of POM have the potential to influence remineralisation rates in addition to changes in bacterial activities in the twilight zone and the deep ocean. For illustrative purposes, we may describe a potential relation between temperature changes in the water column and changes in $\alpha$. Let us assume a spatially uniform temperature change, a constant mean particle settling velocity and that the remineralisation rate of POM is temperature driven and can be de-

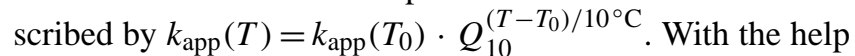
of Eq. (2), a change in $\alpha$ from $\alpha_{0}=0.83$ to $\alpha_{1}=0.77$ translates, for a $Q_{10}$ value of 2 , to a mean change in temperature $\Delta T=10^{\circ} \mathrm{C} \ln \left(\frac{\alpha_{1}}{\alpha_{0}}\right) / \ln \left(Q_{10}\right)=-1.1^{\circ} \mathrm{C}$.

Changing concentrations of atmospheric $\mathrm{CO}_{2}$ as induced by biological changes are not fed back to the radiative code in the standard setup, as this so-called oceanic climate-carbon feedback has been systematically analysed elsewhere (Arora et al., 2013; Plattner et al., 2008; Joos et al., 1999). This implies that the physical part of the model (e.g. ocean circulation) remains unchanged during our experiments.

\section{Results}

\subsection{Changes in the remineralisation length scale of POM}

\subsubsection{Ocean response}

We first analyse changes in fluxes and tracer distributions for an increase in $l_{\text {POM }}$ by $25 \mathrm{~m}$ from 250 to $275 \mathrm{~m}$. This results in a decrease in the fraction of the POM export that is remineralised above $\sim 250 \mathrm{~m}$ and in an increase below (Fig. 2c). These changes affect tracer distributions in the model and in turn surface nutrient availability, productivity, export, deposition, and burial fluxes of POM and calcite (Fig. 3). Both in the open and closed system, the remineralisation of POM at deeper depths leads to a larger surface-to-deep ocean gradient in nutrients, to less nutrients in in the upper thermocline and to less nutrient input into the euphotic zone (note that we only consider changes in remineralisation below the euphotic zone). As a result, surface water concentrations of $\mathrm{PO}_{4}$ decreases leading to a decrease in global export production of $\mathrm{POM}$ and $\mathrm{CaCO}_{3}$ by $\sim 12 \%$ (Fig. $3 \mathrm{~b}$ and c). The reduced export triggers some minor changes in the ecosystem structure in the Southern Ocean, where phosphate depletion favours the growth of diatoms, leading to a local decrease in the export rain ratio. The net effect of the production changes is thus a surface-ocean increase in DIC and Alk, except for the Southern Ocean, where surface Alk remains constant.

The step-wise change in remineralisation depth leads to an initial spike-like increase in POM deposition (Fig. 3d). Then deposition is decreasing in parallel with export, but remains above the initial deposition rate throughout the simulation. The higher deposition leads to a temporary excess of POM burial compared to the closed system (or the weathering input) (Fig. $3 \mathrm{f}$ and h; P and $\mathrm{C}$ fluxes scale with the Redfield ratio of $1: 117)$ and consequently to a decrease in the ocean inventory of phosphate further reducing organic matter production in the euphotic zone. The decrease in POM and calcite exports occurs in two phases. First, the deepening of the remineralisation depth leads to a redistribution of nutrients within the ocean on a multi-decadal to century scale. Second, the whole ocean phosphate inventory and particle export slowly decrease on millennial timescales due to excess burial of POP to reach a new equilibrium when the balance between burial and weathering input of phosphorus is reestablished around 40 to $50 \mathrm{kyr}$ after the step change (Fig. 3f, dashed line).

Next, we discuss the processes and the time evolution of POM and calcite burial, here taken as the flux leaving the ocean at the sediment interface. Increased POM deposition (rain) tends to increase POM burial and to alter POM oxidation. The change in the amount of POM oxsidised in the sediments varies in space and time: in the deep ocean, reduced oxygen availability in the porewater decreases local remineralisation. On the other hand, increased oxygen levels at coastal margins promote the remineralisation in the sediments in these regions. At, equilibrium POM burial rate has 

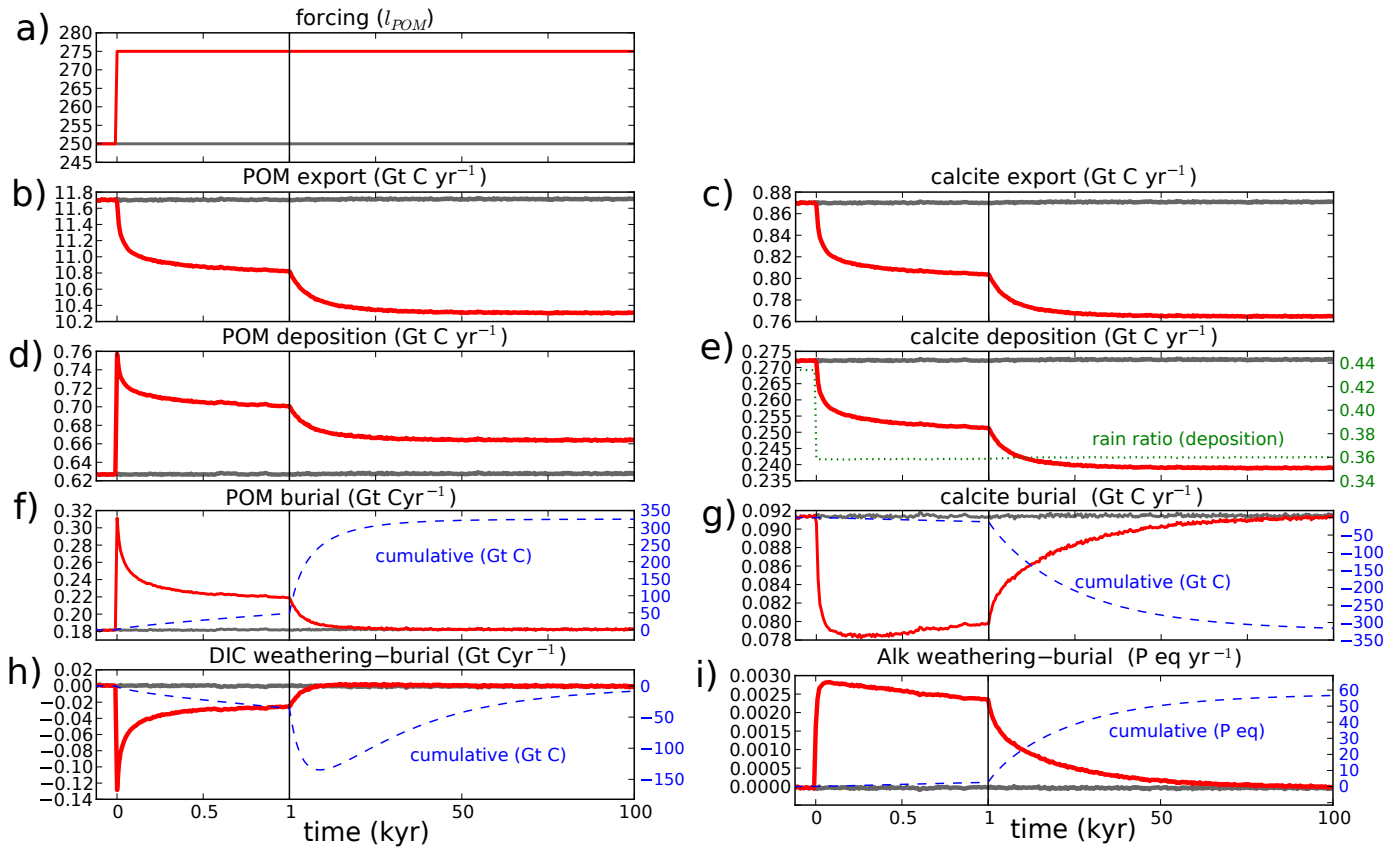

Figure 3. Globally integrated, annual mean fluxes for the control run (grey, $l_{\mathrm{POM}}=250 \mathrm{~m}$ ) and the perturbation experiment (red, $l_{\mathrm{POM}}=275 \mathrm{~m}$ ). Note the different time axis for the first $1 \mathrm{kyr}$. Carbon fluxes are reported in gigatons of carbon $(\mathrm{Gt} \mathrm{C})$ and alkalinity fluxes in petaequivalents (P eq) (left $y$ axis) per year. The blue dashed lines (right $y$ axis) show cumulative fluxes, i.e. cumulative differences w.r.t. the control experiment. Weathering fluxes are kept constant in all experiments. The change in the ratio of the deposition flux of $\mathrm{POC}$ to $\mathrm{CaCO}_{3}$ is shown by the green dotted line in (e).

to balance input of phosphorus by weathering. The result is an initial spike in POM burial by almost $80 \%$, about four times larger than the relative initial increase in deposition, in response to an initial oxygen reduction in the pore water. Afterwards, POM deposition and POM burial decreases quickly within a few centuries and then more slowly to approach steady state over the next millennia. As POM deposition stabilises on a higher level while POM burial relaxes to the initial value, the burial efficiency slightly decreases in the long run by $\sim 5 \%$.

Similarly, the temporal evolution of calcite burial is driven by changes in deposition and redissolution fluxes. Calcite deposition decreases according to the global decrease in primary production and export. As the lysocline shoals as a consequence of the disturbed seawater chemistry $-\mathrm{CO}_{3}^{2-}$ initially decreases in the deep ocean - more sediments are exposed to undersaturated waters, leading to an increased redissolution flux for the first $\sim 5 \mathrm{kyr}$. Thereafter, the lysocline starts to deepen until burial matches weathering input; in the long run, the lysocline deepens by $\sim 800 \mathrm{~m}$ in the Pacific. The result is an initial drop in calcite burial by about $10 \%$ and a very slow recovery to the initial burial rate over the next $100 \mathrm{kyr}$. The imbalance in the burial and weathering fluxes of POM and calcite causes a removal of only $4.2 \times 10^{14} \mathrm{~mol}$ of carbon $(5 \mathrm{GtC})$ from the ocean and the addition of about $55 \times 10^{15}$ equivalent of alkalinity (a mean Alk increase of $\sim 39 \mu \mathrm{mol} \mathrm{L}^{-1}$ ) (Fig. 3h and i). The reduced loss of carbon by decreased calcite burial is largely offset by the enhanced burial of POM, while both a reduced calcite burial and an enhanced POM burial tend to increase ocean alkalinity. Overall, the ocean inventory in DIC is also increased as the ocean absorbs about $70 \mathrm{Gt} C$ from the atmosphere (see next section). The whole ocean phosphorus inventory is affected by the excess POP burial, and decreases by $2.2 \times 10^{14} \mathrm{~mol} \mathrm{P}$.

The adjustment to a new equilibrium takes longer for the alkalinity inventory, co-governing calcite burial than for the phosphorus inventory, co-governing POM burial. $63 \%$ of the final perturbation in the phosphorus and alkalinity inventory is reached after $8.5 \mathrm{kyr}$ (Fig. 3f) and after $32 \mathrm{kyr}$ (Fig. 3i), respectively. The difference in timescales is linked to the difference in mean residence time of $23 \mathrm{kyr}$ for phosphorus $\left(3030 \mathrm{~T} \mathrm{~mol}^{\prime} 0.13 \mathrm{~T} \mathrm{~mol} \mathrm{yr}^{-1}\right)$ and of $253 \mathrm{kyr}$ for alkalinity $\left(3290 \mathrm{P} \mathrm{eq} / 0.013 \mathrm{P} \mathrm{eq} \mathrm{yr}^{-1}\right)$.

Regional changes in the surface concentration of $\mathrm{PO}_{4}$, POM export and POM deposition are distinct (Fig. 4). After $50 \mathrm{kyr} \mathrm{PO}_{4}$ is reduced almost everywhere in the surface ocean (Fig. 4a). Smallest changes are found in the oligothrophic regions where $\mathrm{PO}_{4}$ is already strongly depleted in the control simulation. Relatively large reductions in the Southern Ocean and in the upwelling areas off South America and Africa are simulated. These are linked to the upwelling of less $\mathrm{PO}_{4}$ rich waters as caused by the reduction in the total phosphate inventory of the ocean by excess POP burial. Relatively large reductions are also simulated in the 
subtropical gyres in the Pacific and Atlantic as well as in the eastern Indian where the model features too high $\mathrm{PO}_{4}$ concentrations in the standard setup.

POM export (Fig. 4b) is hardly reduced in the Southern Ocean, while substantial reductions are simulated in equatorial regions and in the northern North Pacific and North Atlantic. POM deposition (Fig. 4c) increases along the productivity belt in the Southern Ocean and in the upwelling regions off South America and Africa and in the northwestern North Pacific. There is also an increase in POM deposition in the eastern tropical Indian Ocean, which is linked to too excessive productivity in this area. In the North Atlantic, the influences of the reduction in POM export and the increase in remineralisation depth on POM deposition nearly cancel.

Next, we discuss the redistribution of tracers within the ocean for the new equilibrium in the closed and open system. The distribution changes in the closed system occur in the first two millennia, while it takes many millennia to approach the equilibrium in the open system. Figure 5 shows the resulting equilibrium anomalies w.r.t. the control simulation for $\mathrm{PO}_{4}$, oxygen, DIC, Alk and $\mathrm{CO}_{3}^{2-}$ in a transect through the Atlantic, Southern Ocean and Pacific (the transect is highlighted in red in Fig. A2b).

In the closed system (i.e. without the sediment module), the ocean's $\mathrm{PO}_{4}$ inventory is conserved, and a deepening of the remineralisation depth leads to a depletion in $\mathrm{PO}_{4}$ in the upper ocean and an increase in the deep (Fig. 5a). The pattern reflects the major transport pathways in the ocean showing reduced $\mathrm{PO}_{4}$ concentration in North Atlantic Deep Water and enhanced concentration in Antarctic Bottom Water in the Atlantic and Pacific. As expected, this pattern is similar in subsurface waters for DIC (Fig. 5e) and inverse for $\delta^{13} \mathrm{C}$ (Fig. 7d) and oxygen (Fig. 5c) as these tracers are linked to $\mathrm{PO}_{4}$ by constant Redfield elemental ratios in biological fluxes. At the same time, $\mathrm{CO}_{3}^{2-}$ and Alk (Fig. $5 \mathrm{~g}$ and i) are slightly increased in the upper part of the water column as less POM is remineralised in the upper ocean (POM remineralisation consumes $\mathrm{Alk}$ ). $\mathrm{CO}_{3}^{2-}$ (and $\mathrm{Alk}$ ) is lowered in the deep as less calcite and more POM is remineralised.

In the setup with the sediment model, downward fluxes of POM (and $\mathrm{CaCO}_{3}$ ) are not remineralised at the seafloor, but are deposited onto the model's sediment layer, and undergo bioturbation, remineralisation and vertical transport. The ocean inventory of $\mathrm{PO}_{4}$, and Alk change substantially in response to excess POM and reduced calcite burial as discussed above. As a result, $\mathrm{PO}_{4}$ is reduced and Alk increased in the entire ocean compared to the control simulation. The changes in DIC are more subtle and regionally distinct. Reduced remineralisation in the thermocline leads to negative anomalies in the Atlantic and Pacific. The increase in Alk causes a change in the partitioning between dissolved $\mathrm{CO}_{2}$, bicarbonate, and carbonate ion. The result is a decrease in $p \mathrm{CO}_{2}$, an increase in carbonate ion, and an increase in DIC in the surface ocean. These positive DIC anomalies are communicated to the deep in the North Atlantic and Southern
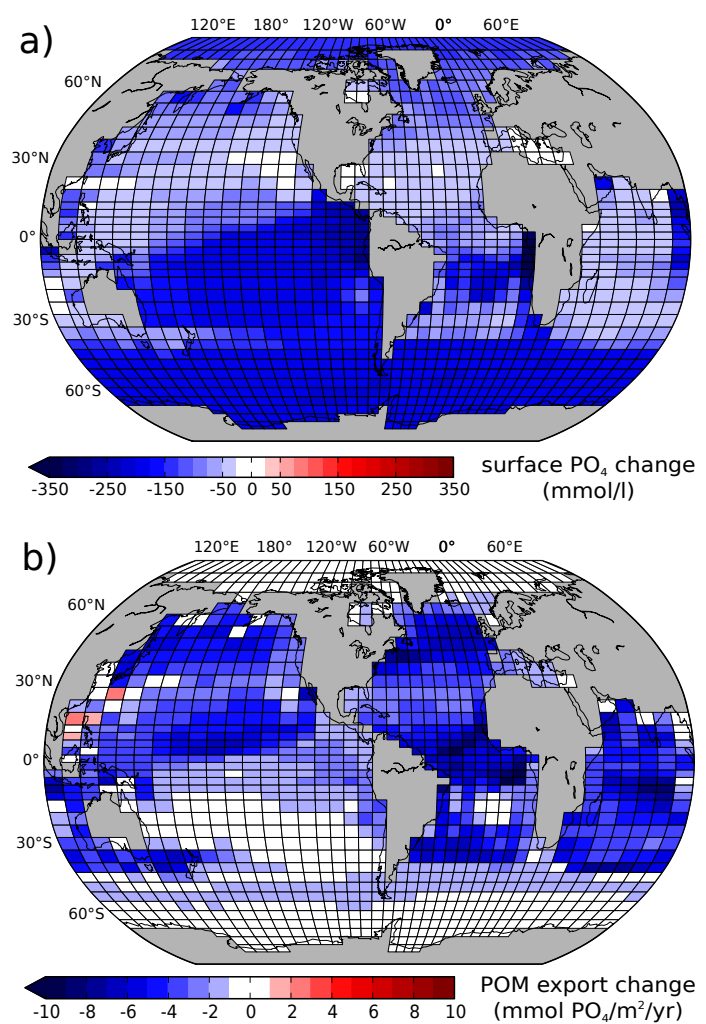

C)

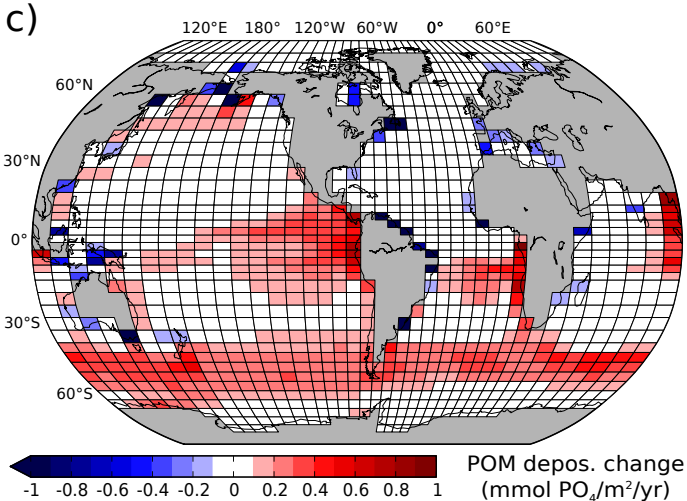

Figure 4. Equilibrium changes in annual mean ocean properties in a POM remineralisation deepening experiment $\left(l_{\mathrm{POM}}\right.$ : $250 \mathrm{~m} \rightarrow 275 \mathrm{~m}$ ). (a) Change in surface (top $80 \mathrm{~m}$ ) seawater $\mathrm{PO}_{4}$ concentration, (b) change in POM export flux and (c) change in seafloor POM deposition rate.

oceans, where the positive DIC anomalies in the Southern Ocean and the deepest layers of the Pacific and Atlantic oceans are partly maintained.

\subsubsection{Response in atmospheric $\mathrm{CO}_{2}$}

We have shown that changes in $l_{\mathrm{POM}}$ lead to a much stronger perturbation in the ocean's carbonate system in an open model driven by the long-lasting imbalance between weathering and burial rates of DIC and Alk. The resulting 
closed system
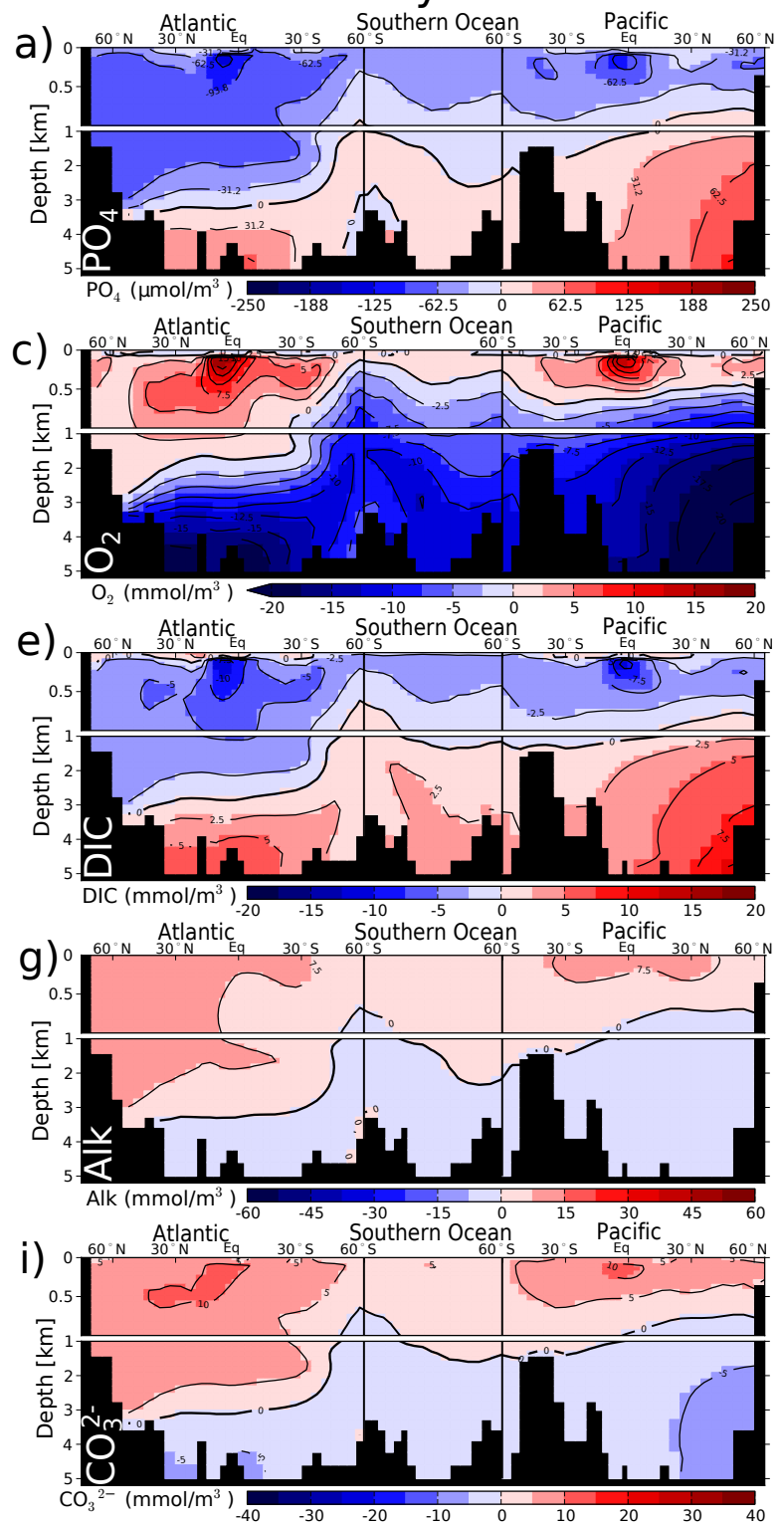
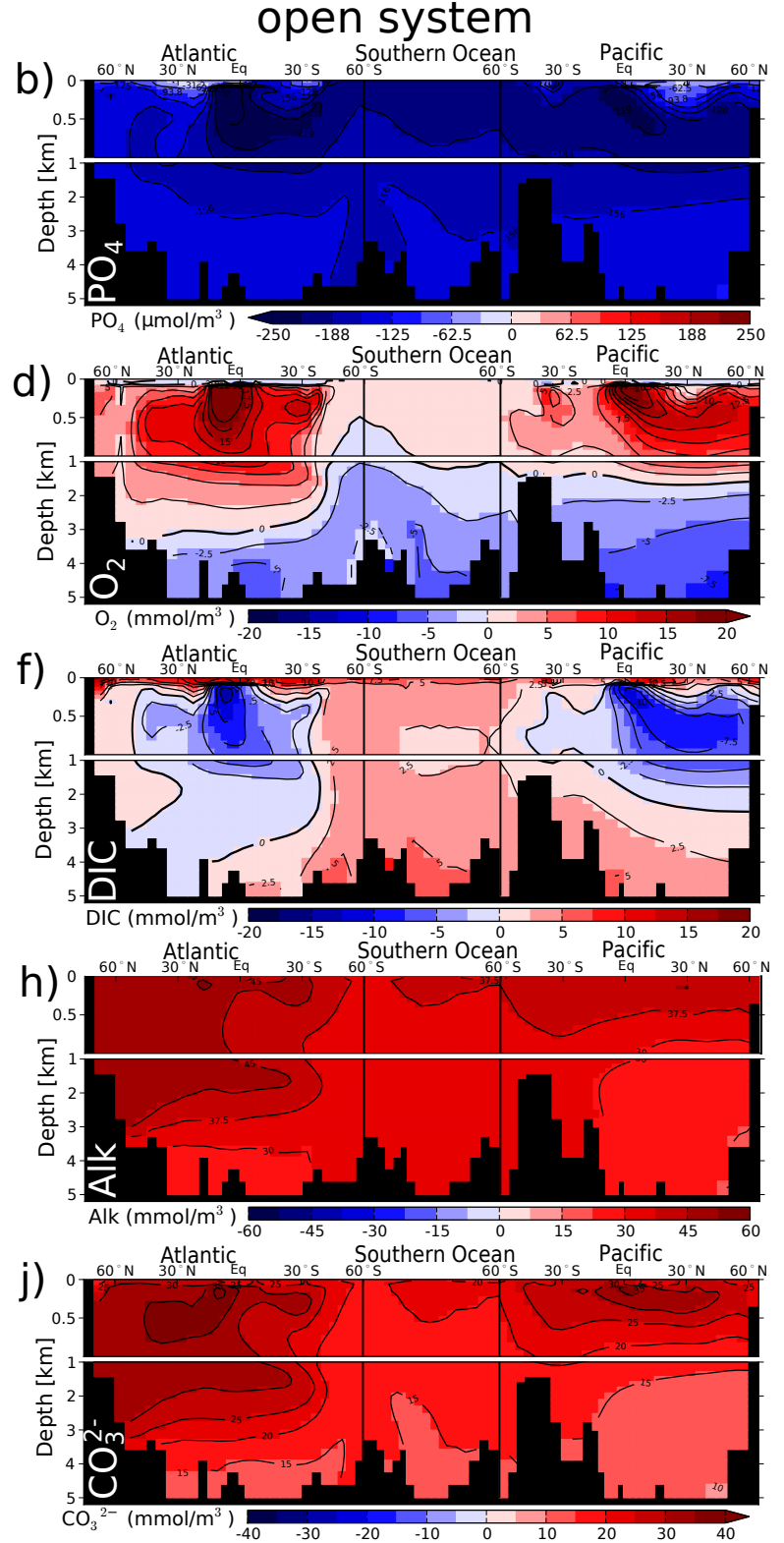

Figure 5. Equilibrium changes in annual mean tracer concentrations in a POM deepening experiment $\left(l_{\mathrm{POM}}: 250 \mathrm{~m} \rightarrow 275 \mathrm{~m}\right) \mathrm{with}$ prognostic changes in export production along a transect through the Atlantic, Southern and Pacific oceans (note that the top $1000 \mathrm{~m}$ are enlarged w.r.t. the deep ocean). Shown are (from the top to bottom panels) changes in concentrations of phosphate, oxygen, dissolved inorganic carbon, alkalinity and carbonate. The experiments have been run both for the closed system (left column panels) as well as for the open system (right column panels).

whole-ocean increase in $\mathrm{CO}_{3}^{2-}$ leads to a decrease in seawater $p \mathrm{CO}_{2}$ at the surface.

How does this influence the atmospheric $\mathrm{CO}_{2}$ concentrations? In Fig. 6a, time series of the initial $50 \mathrm{kyr}$ response are shown for both the closed (black) and open system (red). The magnitude of changes in atmospheric $\mathrm{CO}_{2}$ is $\sim 5$ times higher in the setup with sediments compared to the setup without sediments at year 50000 . Atmospheric $\mathrm{CO}_{2}$ decreased by $33.4 \mathrm{ppm}$ in the open system and by $8.1 \mathrm{ppm}$ in the closed system for a change in $l_{\mathrm{POM}}$ from 250 to $275 \mathrm{~m}$. The $\mathrm{CO}_{2}$ decrease is more than $100 \mathrm{ppm}$ for a change in $l_{\text {POM }}$ to $375 \mathrm{~m}$. Atmospheric $\mathrm{CO}_{2}$ is stabilised after $\sim 2 \mathrm{kyr}$ in the closed system, while at the same time the response in the open system is only $\sim 40 \%$ of the equilibrium response. $62 \%$ of the equilibrium $\mathrm{CO}_{2}$ change are reached after $\sim 10 \mathrm{kyr}$ and $93 \%$ after $\sim 50 \mathrm{kyr}$. The effective e-folding timescale, defined as the time when $63 \%$ of the final anomaly 


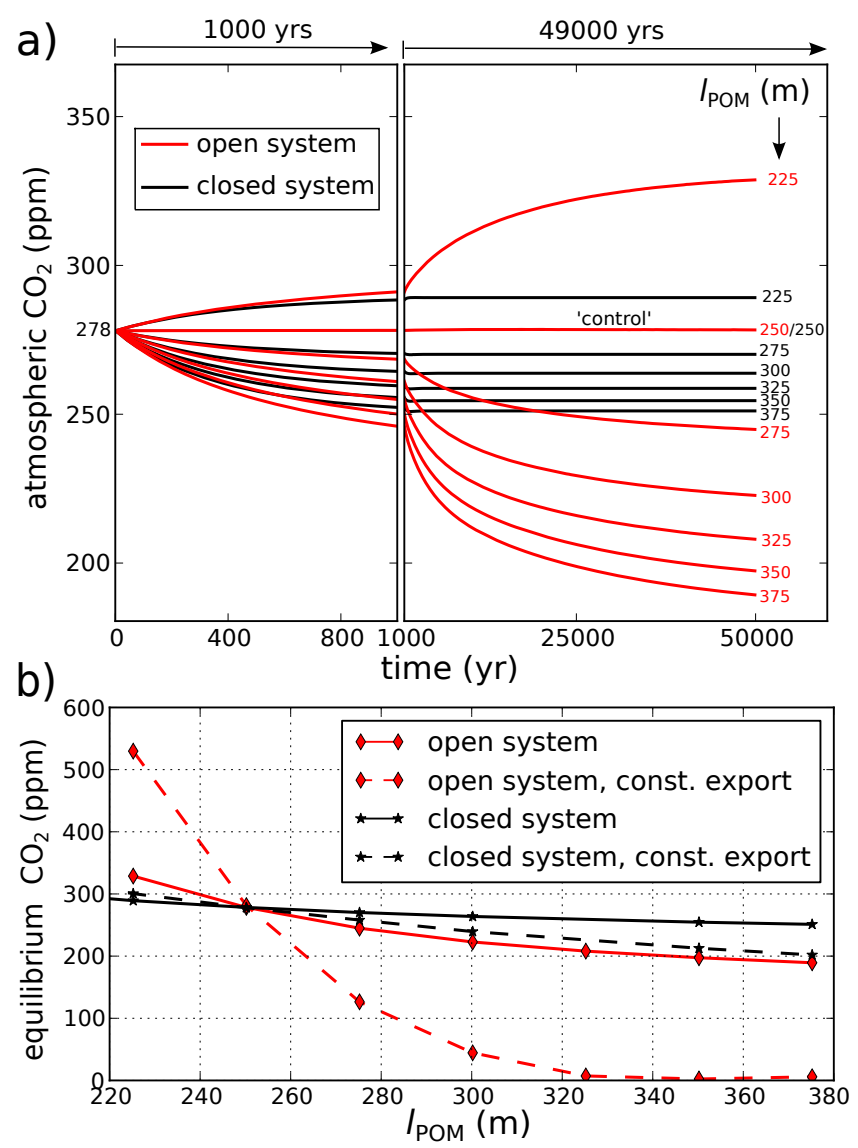

Figure 6. (a) Time evolution of atmospheric $\mathrm{CO}_{2}$ as a result of instantaneous changes in the global POM remineralisation profiles for the open system (red) and the closed system (black). The first $1000 \mathrm{yr}$ of the time axis are enlarged. (b) $\mathrm{CO}_{2}$ for a set of POM remineralisation depths with prognostic (solid lines) and constant (dashed lines) export production. Note that the constant export case does not equilibrate in the open system due to sustained weathering-burial imbalance. The corresponding values were calculated after $50 \mathrm{kyr}$.

is reached, is $\sim 10 \mathrm{kyr}$ in the open system and only $0.5 \mathrm{kyr}$ in the closed system.

Global export production decreases when increasing the remineralisation length scale in the standard model setup. We run a sensitivity experiment to explore the influence of the reduced export flux vs. the change in the remineralisation profile. The export production climatology from the control run is prescribed in these perturbation experiments. As to be expected, changes in $\mathrm{CO}_{2}$ increase by a factor of $\sim 2$ 4 w.r.t. to the standard setup with prognostic production (see Fig. 6b). The constant export flux leads to a constant drain of nutrients and carbon from the ocean as burial fluxes continuously exceed weathering fluxes in the open system. In turn, the oceanic inventories slowly drift towards zero and negative values. Therefore, no equilibrium changes in $\mathrm{CO}_{2}$ can
Table 2. Changes in atmospheric $\mathrm{CO}_{2}$ induced by a global/regional deepening of the depth scale $\left(l_{\mathrm{POM}}\right)$ from $250 \mathrm{~m}$ (control) to $275 \mathrm{~m}$ in the open system. Negative numbers denote a decrease in $\mathrm{CO}_{2}$.

\begin{tabular}{lccc}
\hline Region & $\begin{array}{c}\Delta \mathrm{CO}_{2} \\
(\mathrm{ppm})\end{array}$ & $\begin{array}{c}\Delta \mathrm{CO}_{2} \\
(\mathrm{ppm}) \\
\text { normalised }^{\text {by area }}{ }^{\mathrm{a}}\end{array}$ & $\begin{array}{c}\Delta \mathrm{CO}_{2} \\
(\mathrm{ppm}) \\
\text { normalised } \\
\text { by export }^{\mathrm{b}}\end{array}$ \\
\hline Global & -33.4 & -33.4 & -33.4 \\
$90-30^{\circ} \mathrm{N}$ & -6.9 & -39.5 & -50.1 \\
$30^{\circ} \mathrm{N}-30^{\circ} \mathrm{S}$ & -19.8 & -37.7 & -35.9 \\
$30-90^{\circ} \mathrm{S}$ & -8.9 & -29.5 & -28.5 \\
\hline
\end{tabular}

${ }^{\text {a }}$ The fractional sea surface areas are $90-30^{\circ} \mathrm{N}: 17 \%, 30^{\circ} \mathrm{N}-30^{\circ} \mathrm{S}$ : $52 \%$, and $30-90^{\circ} \mathrm{S}: 30 \%{ }^{\mathrm{b}}$ The fractional export fluxes are $90-30^{\circ} \mathrm{N}: 14 \%, 30^{\circ} \mathrm{N}-30^{\circ} \mathrm{S}: 55 \%$, and $30-90^{\circ} \mathrm{S}: 31 \%$.

be stated for the prescribed production model (Fig. $6 \mathrm{~b}$ shows anomalies after $50 \mathrm{kyr}$ ).

Next, we assess the sensitivity of atmospheric $\mathrm{CO}_{2}$ to $l_{\mathrm{POM}}$ changes in different oceanic regions (Table 2). The hypothesised change in the remineralisation depth may be different in different regions. $l_{\mathrm{POM}}$ is changed in 3 latitudinal bands separately, namely $90-30^{\circ} \mathrm{N}, 30^{\circ} \mathrm{N}-30^{\circ} \mathrm{S}$ and $30-90^{\circ} \mathrm{S}$. The sum of the $\mathrm{CO}_{2}$ changes for the three regional experiments is with $35.6 \mathrm{ppm}$ only slightly larger than for the global experiment $(33.4 \mathrm{ppm})$. The tropical band covers the largest sea surface area $(52 \%)$ and most of the global POM export flux $(\sim 55 \%)$. For a change of $l_{\mathrm{POM}}$ from 250 to $275 \mathrm{~m}$, the tropical band alone contributes $\sim 60 \%$ of the $\mathrm{CO}_{2}$ change. The effectiveness of $l_{\mathrm{POM}}$ changes per unit area or per unit POM export to reduce $\mathrm{CO}_{2}$ is different for different regions (Table 2). Normalised sensitivities are highest in the northern extratropical band, likely linked to an efficient propagation of anomalies by North Atlantic Deep Water.

\subsubsection{Carbon isotopes}

Next, we further discuss the response in $\delta^{13} \mathrm{C}$ of DIC and of atmospheric $\mathrm{CO}_{2} \cdot \delta^{13} \mathrm{C}$ of atmospheric $\mathrm{CO}_{2}$ is closely coupled through air-sea exchange to $\delta^{13} \mathrm{C}$ of DIC in the surface ocean. We start with the closed system response. The spatiotemporal response in $\delta^{13} \mathrm{C}$ of DIC mirrors that of $\mathrm{PO}_{4}$ as the marine biogeochemical cycles of $\mathrm{P}$ and $\mathrm{C}$ and ${ }^{13} \mathrm{C}$ are coupled. The deepening of $l_{\mathrm{POM}}$ leads to less remineralisation of isotopically light $(\sim-20 \%$ o) POM in the upper ocean and more remineralisation in the deep. In turn $\delta^{13} \mathrm{C}$ of DIC in the deep ocean decreases and $\delta^{13} \mathrm{C}$ at depths shallower than $\sim 1000 \mathrm{~m}$ increases (Fig. 7d). In addition, the decrease in surface water concentration of $\mathrm{CO}_{2}$ leads to slightly less negative values of the fractionation factor for photosynthesis and thus for the transformation of inorganic carbon to POC; this tends to slightly decrease $\delta^{13} \mathrm{C}$ in the surface ocean. The result is an increase in surface ocean and atmospheric $\delta^{13} \mathrm{CO}_{2}$ by $\sim 0.03 \%$ within $2 \mathrm{kyr}$ (Fig. $7 \mathrm{a}$ and d). 

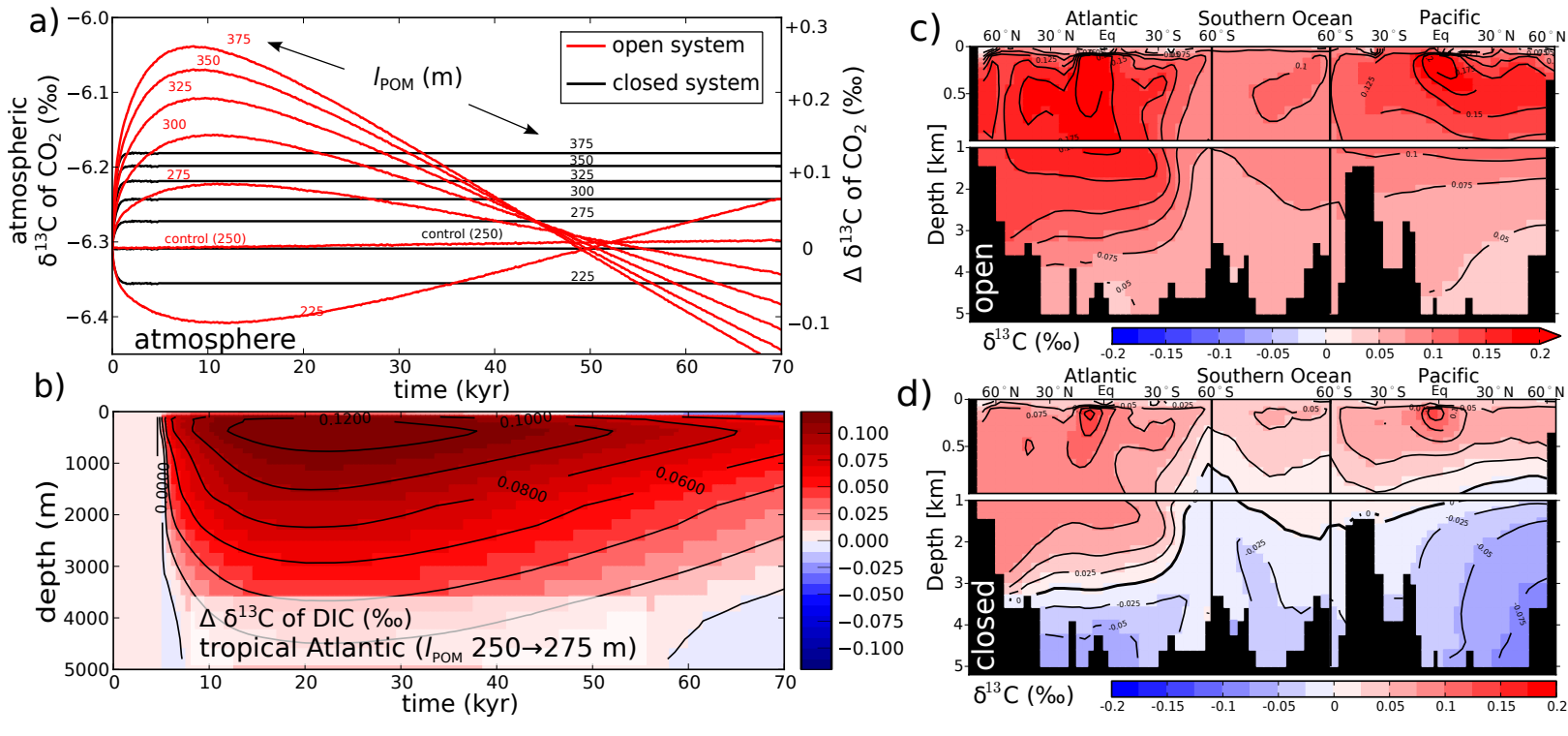

Figure 7. (a) Time evolution of the stable isotope ${ }^{13} \mathrm{CO}_{2}$ mixing ratio, expressed as $\delta^{13} \mathrm{C}$ of $\mathrm{CO}_{2}$, for a set of different POM remineralisation depths. The black line shows the response in the closed system, while the red lines show the evolution in the open system. (b) Hovmöller diagram of the change in $\delta^{13} \mathrm{C}$ of DIC averaged over the tropical Atlantic. (c, d) Anomaly in $\delta^{13} \mathrm{C}$ of DIC in the POM deepening experiment after $15 \mathrm{kyr}$ in the open and closed systems in a transect through the Atlantic, Southern and Pacific oceans.

Additional processes are important for the evolution of $\delta^{13} \mathrm{C}$ of DIC and $\mathrm{CO}_{2}$ in the open system. (i) The excess burial of isotopically light $\mathrm{POC}\left(\delta^{13} \mathrm{C} \approx-20 \%\right)$ during the first $\sim 50 \mathrm{kyr}$ tends to increase the average $\delta^{13} \mathrm{C}$ signature in the ocean-atmosphere system; the $\delta^{13} \mathrm{C}$ signature of the POC burial flux is, at $-20 \%$, about $7 \%$ o lower than the signature of the total carbon weathering-burial flux $(-12.6 \%$ ). (ii) Similarly, burial of isotopically enriched calcite $\left({ }^{13} \mathrm{C} \sim 3 \%\right.$ o) is reduced (relative to initial conditions and the weathering flux) during the first $\sim 100 \mathrm{kyr}$; this tends to increase $\delta^{13} \mathrm{C}$ during this period; the calcite burial flux is enriched by about $15 \%$ o compared to the average signature of the weathering-burial flux. (iii) The reduction in surface $\mathrm{CO}_{2}$ is, at $33 \mathrm{ppm}$, about 4 times larger in the open system than in the closed system for an increase in $l_{\mathrm{POM}}$ to $275 \mathrm{~m}$. This results in a less negative fractionation factor for POM formation (Freeman and Hayes, 1992) and tends to decrease ${ }^{13} \mathrm{C}$ in the surface. (iv) At the new equilibrium, the input of ${ }^{13} \mathrm{C}$ by weathering must balance the loss of ${ }^{13} \mathrm{C}$ by burial, as is the case for the flux of POC and calcite (Fig. 8). The consequence is that the positive shift in the POC fractionation factor leads to a loss of ${ }^{13} \mathrm{C}$ from the ocean until it is balanced by a corresponding negative anomaly in ${ }^{13} \mathrm{C}$ of DIC in surface waters communicated to the $\mathrm{POC}$ and calcite burial fluxes.

In the surface ocean and the atmosphere, $\delta^{13} \mathrm{C}$ increases during roughly the first $10-15 \mathrm{kyr}$ by $0.08 \%$ in response to the closed system processes and in response to the anomalies in POC and calcite burial. Then, $\delta^{13} \mathrm{C}$ decreases and the anomalies in $\delta^{13} \mathrm{C}$ turn negative around $50 \mathrm{kyr}$ followed by a further decrease until the end of the simulation in response to (iii) and (iv). The fractionation factor (expressed here as $\epsilon=1000 \cdot(\alpha-1)$ ) for photosynthesis (POC formation) changes roughly in parallel with surface ocean and atmospheric $\mathrm{CO}_{2}$. It increases by $0.8 \%$ from -13.2 to $-12.4 \%$ in the global average during the first $\sim 100 \mathrm{kyr}$ in the simulation where $l_{\mathrm{POM}}$ equals $275 \mathrm{~m}$ (Fig. 8a). In turn, the $\delta^{13} \mathrm{C}$ signature of the POM burial flux increases by about $0.55 \%$ and starts to decreases only after about $50 \mathrm{kyr}$ (Fig. 8b). $\delta^{13} \mathrm{C}$ of the burial flux of calcite closely follows the evolution of $\delta^{13} \mathrm{C}$ in the surface-atmosphere system. The whole ocean's ${ }^{13} \mathrm{C}$ inventory is driven by changes in the $\delta^{13} \mathrm{C}$ burial flux, expressed as the burial flux of $\mathrm{C}$ times its isotopic signature in \%o. The ${ }^{13} \mathrm{C}$ burial (Fig. $8 \mathrm{c}$ and d) is thus a convolution of the total $\mathrm{C}$ burial, the particle's $\delta^{13} \mathrm{C}$ and the POCto-calcite ratio in the burial flux. The new equilibrium with zero $\delta^{13} \mathrm{C}$ anomaly in the total burial flux is only achieved after the end of the simulation (200 kyr) (Fig. 8d). At the end of the simulation, the whole-ocean ${ }^{13} \mathrm{C}$ of DIC (and DOC) is still relaxing from its initial perturbation and a stabilisation is expected to take another $200 \mathrm{kyr}$ or so (Fig. 8e). These long response timescales are a result of the convolution of multiple slow processes and weak negative (stabilising) feedbacks.

The effect on the radioactive carbon isotope ${ }^{14} \mathrm{C}$ is small compared to past natural variations. $\Delta^{14} \mathrm{C}$ of atmospheric $\mathrm{CO}_{2}$ increases by $\sim 12 \%$ o ( $\sim 3 \%$ o in the closed system $)$. A constant rate of atmospheric ${ }^{14} \mathrm{C}$ production is applied. The increase can be attributed to the lower atmospheric $\mathrm{CO}_{2}$ concentration, or more generally, to the lower carbon inventory in the (open) system. The biologically mediated fluxes of ${ }^{14} \mathrm{C}$ 


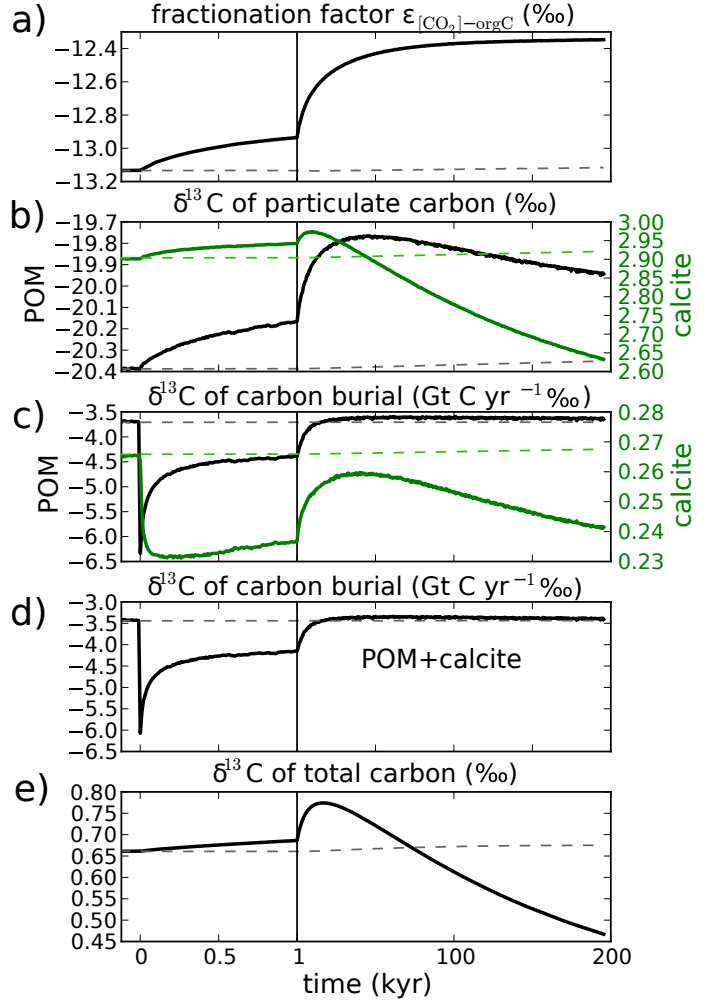

Figure 8. Time evolution of the oceanic ${ }^{13} \mathrm{C}$ budget. (a) Fractionation during organic $\mathrm{C}$ formation (photosynthesis) expressed as $\epsilon=1000 \cdot(\alpha-1)$. (b) Isotopic signatures of particulate carbon in POM (black, left axis) and calcite (green, right axis). Burial of ${ }^{13} \mathrm{C}$ expressed as the C-burial flux times its isotopic signature in \%o is shown in (c) for POM (black, left axis) and calcite (green, right axis), and for the total burial in (d). (e) Average $\delta^{13} \mathrm{C}$ signature of the carbon in the atmosphere-ocean system.

within the ocean are small compared to the fluxes driven by advection, convection, and mixing. This explains the small sensitivity of $\Delta^{14} \mathrm{C}$ to changes in the marine biological cycle.

\section{$3.2 I_{\text {calc }}$ changes}

It has been suggested that changes in the rate of $\mathrm{CaCO}_{3}$ dissolution in the upper ocean will be a significant feedback affecting atmospheric $\mathrm{CO}_{2}$ concentrations and future climatic changes (e.g. Barrett et al., 2014). To this end, we prescribe in a further set of sensitivity simulations a step change in the e-folding dissolution length scale $l_{\text {calc }}$ governing the dissolution profile of $\mathrm{CaCO}_{3}$ particles within the water column (see Eq. 6), $l_{\text {calc }}$ is changed at the end of the spin up from its standard value of $2900 \mathrm{~m}$ to values ranging from 2100 to $3700 \mathrm{~m}$; then the run is continued for another 50,000 years with the new value of $l_{\text {calc }}$. Export fluxes both of $\mathrm{POC}$ and $\mathrm{CaCO}_{3}$ remain constant as changes in the dissolution of $\mathrm{CaCO}_{3}$ do not affect productivity in our model.
The experimental setup with the assumption of an efolding remineralisation profile for $\mathrm{CaCO}_{3}$ particles (Eq. 6) is highly idealised. The mechanisms for the dissolution of calcite and other forms of $\mathrm{CaCO}_{3}$ (e.g. aragonite or highmagnesium calcite) within the water column are quantitatively not well understood. Generally, dissolution of $\mathrm{CaCO}_{3}$ particles within the water column is thought to be linked to low (undersaturated) concentration of carbonate ions in the surrounding water. However, considerable $\mathrm{CaCO}_{3}$ dissolution may occur in the upper ocean (Berelson et al., 2007) in waters that are saturated with respect to $\mathrm{CaCO}_{3}$ in the mineral form of calcite or even of aragonite, perhaps due to the dissolution of high-magnesium calcite or due to dissolution in specific microenvironments such as zooplankton guts, fecal pellets or organic aggregates (see e.g. Barrett et al., 2014, and references therein). Here, we do not explicitly take into account such effects, and the dissolution is for example not affected by changes in the calcite saturation horizon (the depth where the concentration of calcium times the concentration of carbonate equals the solubility product of calcite; Mucci, 1983).

The results for these additional sensitivity experiments are as follows. A deepening of $l_{\text {calc }}$ (i.e. a lower calcite redissolution rate) leads to an increase of dissolution products - DIC and Alk - in the deep ocean (below $\sim 3 \mathrm{~km}$ ) and a decrease above. This tends to hinder redissolution of calcite from sediment in the deepest layers. Calcite deposition on sediments and burial both increase in response to the increased dissolution length scale. As a consequence, Alk and DIC burial and thus the removal from the ocean increase with a ratio of $2: 1$. In the long run, the balance between weathering input and burial is reestablished by the following process. The removal of Alk and DIC causes an upward shift in the lysocline. In turn, a larger fraction of the calcite deposition flux is redissolved, and less is buried.

The ocean inventories of DIC and Alk are both perturbed towards lower values when $l_{\text {calc }}$ is increased. This is different to a deepening of the remineralisation depth for POM, where the Alk and DIC budgets are perturbed in opposite directions. As a result, atmospheric $\mathrm{CO}_{2}$ is less sensitive to changes in $l_{\text {calc }}$ than to changes in $l_{\mathrm{POM}}$. For example, a global deepening of $l_{\text {calc }}$ from 2900 to $3300 \mathrm{~m}$ results in an increase in $\mathrm{CO}_{2}$ by $12.2 \mathrm{ppm}$ in the open system (and only $1.8 \mathrm{ppm}$ in the closed system). Although the absolute sensitivity is lower than for $l_{\mathrm{POM}}$, the amplification by weathering-burial dynamics is even more pronounced, with an $\sim$ seven-fold higher response in the open than in the closed system. As oceanic $\delta^{13} \mathrm{C}$ of DIC is primarily controlled by the organic matter cycle, changes in $l_{\text {calc }}$ only marginally influence ${ }^{13} \mathrm{CO}_{2}$, such that the signal is too low to separate it from model-internal variability and drift. 
Table 3. Equilibrium changes in atmospheric $\mathrm{CO}_{2}$ and ${ }^{13} \mathrm{CO}_{2}$ (expressed as $\delta^{13} \mathrm{C}$ ) induced by a global change in the mean remineralisation depth of POM and the calcite redissolution length scale.

\begin{tabular}{|c|c|c|c|c|}
\hline & \multicolumn{2}{|c|}{ Closed system } & \multicolumn{2}{|c|}{ Open system } \\
\hline & $\Delta \mathrm{CO}_{2}$ & $\Delta \delta^{13} \mathrm{CO}_{2}$ & $\Delta \mathrm{CO}_{2}$ & $\Delta \delta^{13} \mathrm{CO}_{2}{ }^{\mathrm{a}}$ \\
\hline$l_{\mathrm{POM}}: 250 \mathrm{~m} \rightarrow 275 \mathrm{~m}$ & $-8.1 \mathrm{ppm}$ & $0.037 \%$ & $-33.4 \mathrm{ppm}$ & $0.084 \%$ \\
\hline$l_{\mathrm{POM}}: 250 \mathrm{~m} \rightarrow 225 \mathrm{~m}$ & $10.8 \mathrm{ppm}$ & $-0.046 \%$ o & $50.4 \mathrm{ppm}$ & $-0.10 \%$ \\
\hline Sensitivity & $0.38 \mathrm{ppm} \mathrm{m}^{-1}$ & $-0.0017 \% \circ \mathrm{m}^{-1}$ & $1.68 \mathrm{ppm} \mathrm{m}^{-1}$ & $-0.0037 \% \circ \mathrm{m}^{-1}$ \\
\hline$l_{\text {calc }}: 2900 \mathrm{~m} \rightarrow 3300 \mathrm{~m}$ & $1.8 \mathrm{ppm}$ & $-\mathrm{b}$ & $12.2 \mathrm{ppm}$ & $-\mathrm{b}$ \\
\hline$l_{\text {calc }}: 2900 \mathrm{~m} \rightarrow 2500 \mathrm{~m}$ & $-2.1 \mathrm{ppm}$ & $-b$ & $-14.6 \mathrm{ppm}$ & $-{ }^{b}$ \\
\hline Sensitivity & $0.0049 \mathrm{ppm} \mathrm{m}^{-1}$ & $-b$ & $0.034 \mathrm{ppm} \mathrm{m}^{-1}$ & $-b$ \\
\hline
\end{tabular}

${ }^{a}$ Maximum anomaly is stated (i.e. after $\sim 10-15 \mathrm{kyr}$ ). ${ }^{\mathrm{b}}$ Changes in $\delta^{13} \mathrm{CO}_{2}$ are too small to be separated from model drift.

a)

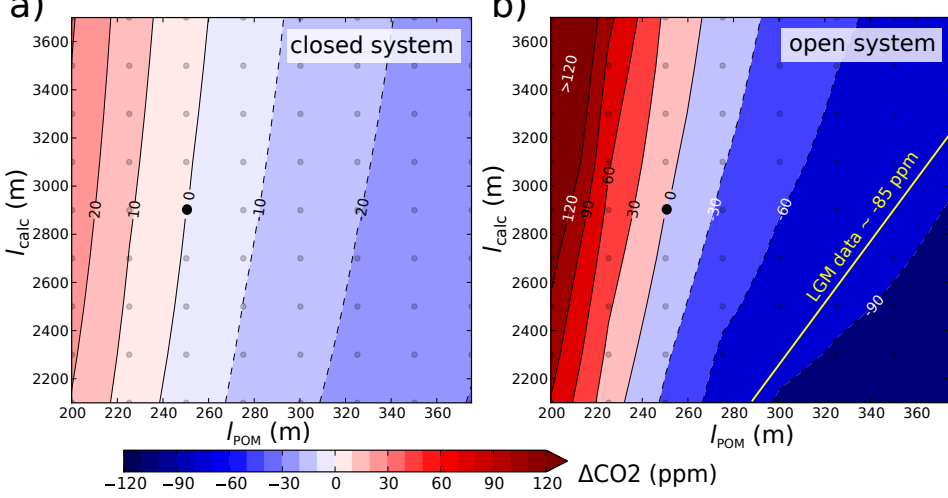

c)

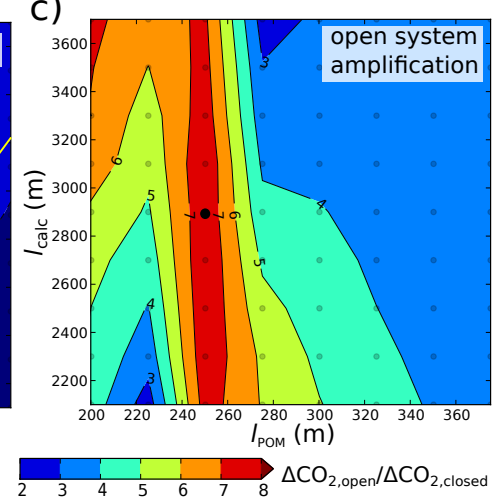

Figure 9. $\Delta \mathrm{CO}_{2}$ as a function of the length scale for the remineralisation of $\mathrm{POM}\left(l_{\mathrm{POM}}\right)$ and the length scale for the dissolution of $\mathrm{CaCO}_{3}$ $\left(l_{\text {calc }}\right)$. Values are differences with respect to the control experiment with $l_{\mathrm{POM}}=250 \mathrm{~m}$ and $l_{\text {calc }}=2900 \mathrm{~m}$ (black dots) and for equilibrium (see main text). Remineralisation/redissolution lengthscale changes are altered globally in these experiments. (a) is for a closed system, and (b) for an open system, i.e. a setup allowing for weathering-burial dynamics. The $\mathrm{LGM} \mathrm{CO}_{2}$ anomaly w.r.t. the Holocene ( $\sim 85$ ppm) is indicated by the yellow line. (c) shows the amplification of $\mathrm{CO}_{2}$ changes due to weathering-burial dynamics.

\subsection{Sensitivities and sediment feedback quantification}

In the following, sensitivities to changes in remineralisation depth are calculated from an experiment where $l_{\mathrm{POM}}$ is reduced by $25 \mathrm{~m}$ and an experiment where it is increased by $25 \mathrm{~m}$ (Table 3). The difference in $\mathrm{CO}_{2}$ or $\delta^{13} \mathrm{C}$ between the two experiments is divided by $50 \mathrm{~m}$, the total change in the e-folding depth. This corresponds to a sensitivity calculated symmetrically around the standard (best-guess) value. In general, atmospheric $\mathrm{CO}_{2}$ responds more sensitively to a shoaling of $l_{\mathrm{POM}}$ and $l_{\text {calc }}$ than to a deepening. The equilibrium sensitivity of atmospheric $\mathrm{CO}_{2}$ to changes in $l_{\mathrm{POM}}$ is $\sim 1.68 \mathrm{ppm} \mathrm{m}^{-1}$ in the open system, and about 4 times lower, $0.38 \mathrm{ppm} \mathrm{m}^{-1}$, in the closed system. Sensitivities in ${ }^{13} \mathrm{CO}_{2}$ (Table 3 ) are less amplified by the weatheringburial loop due to $p \mathrm{CO}_{2}$-induced changes in the fractionation factor.

Next, combined changes in $l_{\mathrm{POM}}$ and $l_{\text {calc }}$ are examined. We sampled the two-dimensional parameter space and integrated each model for $20 \mathrm{kyr}$. To get equilibrium changes in atmospheric $\mathrm{CO}_{2}$, a linear combination of four exponential functions with different timescales is fitted to the response of the first $20 \mathrm{kyr}$. The equilibrium response is then found analytically for $t \rightarrow \infty$. The result of this exercise is shown in Fig. 9a and b. As indicated by the green line in Fig. 9b, $\mathrm{LGM} \mathrm{CO}_{2}$ levels could e.g. be reached by changing $l_{\mathrm{POM}}$ to $\sim 345 \mathrm{~m}$. This number is reduced if $l_{\text {calc }}$ is decreased simultaneously. In the closed system on the other hand, $\mathrm{LGM} \mathrm{CO}_{2}$ levels are far from being reconcilable within the bounds of our parameter sampling. The amplification in the response of $\mathrm{CO}_{2}$ is calculated as the ratio $\Delta \mathrm{CO}_{2 \text {,open }} / \Delta \mathrm{CO}_{2 \text {,closed }}$ and is shown in Fig. 9c. The sediment amplification range is 3-7 for changes in $l_{\mathrm{POM}}$ and $7-8$ for changes in $l_{\text {calc }}$.

\section{Discussion and conclusion}

We systematically mapped the spatio-temporal responses for a variety of tracers and proxies to changes in the remineralisation depth of organic matter and calcium carbonate. The Bern3D dynamic ocean model including sediment 
interactions with organic matter, opal and calcium carbonate is applied. It is shown that on long timescales, ocean-sediment interaction and the weathering-burial cycle strongly amplify the ocean-only response in atmospheric $\mathrm{CO}_{2}, \delta^{13} \mathrm{C}$, ocean tracers and particle export fluxes. These processes also lead to sustained changes in whole ocean nutrient and alkalinity inventories. The adjustment to the new steady state occurs on a number of timescales. Ocean-only reorganisations take place within decades to centuries, and most of the changes in particle export occur within less than $2 \mathrm{kyr}$, while the adjustment of the phosphate and alkalinity inventories occurs on a typical timescale of about 10-30 kyr. Even longer timescales are involved in the evolution of $\delta^{13} \mathrm{C}$. $\delta^{13} \mathrm{C}$ signatures are not yet in equilibrium after $200 \mathrm{kyr}$, the end of our simulations. This implies, as already highlighted by Tschumi et al. (2011), albeit for other mechanisms, that ocean-sediment interactions and the burial-weathering cycles must be considered when discussing the long-term evolution of atmospheric $\mathrm{CO}_{2}$ and $\delta^{13} \mathrm{C}$.

Our model study is associated with a number of limitations. The experiments are idealised and not intended to track the evolution of palaeoproxy signals directly. Changes in remineralisation rates of particulate organic matter (POM) and calcium carbonate $\left(\mathrm{CaCO}_{3}\right)$ are treated in a parameterised, globally uniform way using a power law and an exponential scaling for the attenuation of POM and $\mathrm{CaCO}_{3}$ fluxes with depth. It is a task for future research to advance the mechanistic understanding of the processes governing particle fluxes and remineralisation rates. Furthermore, the Bern3D model is a coarse resolution model with simple parameterisations for the productivity of organic matter, opal, and $\mathrm{CaCO}_{3}$, and fixed Redfield ratios are applied. Productivity is linked to phosphate, as well as to iron and silicic acid, but not to nitrogen compounds. Thus, responses in the nitrogen cycle are not taken into account and these may alter in particular the response in export production. Implicitly, the setup corresponds to the assumption that nitrogen fixers make up for the loss of nitrogen by POM burial to the extent needed to support production. Our model does not include a comprehensive ecosystem model, and may underestimate the shift in ecosystem structures due to the nutrient drawdown as induced by the slowed POM remineralisation. For example, Segschneider and Bendtsen (2013) find an opposite effect of nutrient (i.e. nitrate) depletion on surface Alk using a more complex biogeochemistry model.

There are also limitations regarding the sediment model. For example, the spatio-temporal variability in the deposition of mineral particles or the influence of particle grain size on organic matter preservation is neglected. The coarse resolution hampers the representation of coastal and continental boundaries, where most POM deposition, remineralisation and burial occurs (e.g. Wallmann et al., 2012). The model does not resolve river deltas and estuaries and their carbon cycle (e.g. Regnier et al., 2013). Another caveat is that denitrification within the sediment is not represented by our model, eventually leading to a bias in the long-term response of POM degradation and thus burial efficiencies. Therefore, our findings are to be confirmed and refined by a higherresolved ocean model with a more complete representation of sediment processes.

The starting point for all sensitivity experiments is a steady state corresponding to preindustrial conditions, and sensitivity of results may vary somewhat between different background states. A further caveat in our model could be that weathering rates are kept constant. On timescales of several $10 \mathrm{kyr}$ riverine input of tracers are thought to adapt to changes in climatic conditions as well as in $p \mathrm{CO}_{2}$ (e.g. Colbourn et al., 2013, and references therein). As this negative feedback is not included in our model, the long-term response may be overestimated. Slowed bacterial degradation of POM may also imply a change in the mean lifetime of DOM, which we kept constant in our experiment. The impact of a corresponding increase in DOM lifetime is found to weaken the overall response in $\mathrm{CO}_{2}$ to a change in remineralisation depth of POM by about $15 \%$ (Menviel et al., 2012). Finally, we did not take into account the radiative feedback associated with altered $\mathrm{CO}_{2}$ to ease interpretation of results. The climate-carbon feedback is positive in our model, and its inclusion would yield an even larger change in atmospheric $\mathrm{CO}_{2}$. Despite these numerous caveats, we expect that our experiments will provide the first-order response to changes in the remineralisation depth of $\mathrm{POM}$ and $\mathrm{CaCO}_{3}$.

The results show a high sensitivity of atmospheric $\mathrm{CO}_{2}$ to changes in the POM remineralisation depth. A new element, compared to earlier work with dynamic three-dimensional ocean models, is that changes in the POM remineralisation rate not only change the atmosphere-ocean partitioning of carbon, but also impact the long-term carbon cycle by disturbing the weathering-burial balance of carbon, alkalinity and nutrients. This temporary imbalance amplifies the ocean-atmosphere-only response by a factor of $\sim 3-$ 7 on multi-millennial timescales. A subtle shift of $1 \mathrm{~m}$ (or $4 \%$ ) in the length scale of POM remineralisation causes a change in atmospheric $\mathrm{CO}_{2}$ of almost $2 \mathrm{ppm}$. Our results are in quantitative agreement with Kwon et al. (2009) and Matsumoto (2007) when sediment interactions are neglected. Matsumoto (2007) find a sensitivity in atmospheric $\mathrm{CO}_{2}$ corresponding to about 7-8 ppm per degree warming and assuming a $Q_{10}$ factor for remineralisation of 2 . Kwon et al. (2009) find - for $l_{\mathrm{POM}}$ deepening of $24 \mathrm{~m}-\mathrm{a} \mathrm{CO}_{2}$ reduction of $10 \mathrm{ppm}$ using a nutrient restoring formulation of export production (and $27 \mathrm{ppm}$ with constant export) with a model of comparable complexity, but without taking into account ocean-sediment interactions. In our model featuring prognostic export, we find a reduction of $8 \mathrm{ppm}$ in our closed system setup, i.e. without sediment interactions, for $l_{\text {POM }}$ deepening of $25 \mathrm{~m}$. In the open system, weatheringburial dynamics increase the response four-fold to $33 \mathrm{ppm}$. It has been suggested that changes in the rate of $\mathrm{CaCO}_{3}$ dissolution in the upper ocean may be a significant feedback 
affecting atmospheric $\mathrm{CO}_{2}$ concentrations and future climatic changes (Barrett et al., 2014). In our sensitivity experiments, we varied the e-folding dissolution length scale between 2300 and $3500 \mathrm{~m}$, and thereby the amount of $\mathrm{CaCO}_{3}$ dissolution in near-surface water and the upper ocean. These variations have a relatively small influence on atmospheric $\mathrm{CO}_{2}$ in our model on both century (Fig. 9a) and glacialinterglacial timescales (Fig. 9b). This is consistent with the results of Gangstø et al. (2011), who applied the PISCES ecosystem model with $\mathrm{CaCO}_{3}$ production in the form of calcite and aragonite over the industrial period and in future scenarios. However, these authors restricted the dissolution of $\mathrm{CaCO}_{3}$ to waters that are undersaturated with respect to calcite and aragonite and thus to deeper layers (in particular for calcite), and did not apply a sediment model. Taken together, changes in upper ocean and deep ocean remineralisation rates of $\mathrm{CaCO}_{3}$ appear to exert a small influence on atmospheric $\mathrm{CO}_{2}$ and thus climate.

The idea of the glacial drawdown of nutrients and carbon from the surface to the deep ocean - either by a more stratified ocean and more sluggish ventilation of the deep ocean or other alterations of the marine biological cycle - and as a consequence, the build-up of old respired carbon, has been widely discussed (Boyle, 1988). Evidence for increased glacial storage of respired carbon comes from oxygen-sensitive sediment proxies which show that the oxygenation was decreased during glacials. As deep glacial $\mathrm{Cd} / \mathrm{Ca}$ ratio in the North Pacific, a proxy for $\mathrm{PO}_{4}$, was not increased, these findings lead to the "respired-carbon deepening hypothesis" which denote an increase in remineralised : preformed nutrient supply to the deep ocean (Jaccard et al., 2009; Bradtmiller et al., 2010; Jaccard and Galbraith, 2011). Figure 10 shows the ratio of remineralised : preformed nutrients $\left(\mathrm{PO}_{4}\right.$,rem $\left./ \mathrm{PO}_{4, \text { pre }}\right)$ in our model - based on apparent oxygen utilisation - as well as the change in this ratio induced by an increase in $l_{\text {POM. }}$. A $25 \mathrm{~m}$ increase in the e-folding depth of POM remineralisation leads indeed to a widespread increase in $\mathrm{PO}_{4, \text { rem }} / \mathrm{PO}_{4}$,pre by $\sim 3 \%$ in the global average. The response in $\mathrm{CO}_{2}$ to a deepening of the remineralisation depth evolves on timescales that are much longer than the typical duration of the transition from a glacial to an interglacial state, e.g. $\sim 7 \mathrm{kyr}$ for termination I. As noted by Menviel et al. (2012), this mechanism can thus not explain, at least not in isolation, the relatively rapid increase in $\mathrm{CO}_{2}$ over glacial terminations. In agreement, the whole ocean increase in Alk and $\mathrm{CO}_{3}^{2-}$ resulting over long timescales from a deeper remineralisation depth is not observed in proxy records, which show little glacialinterglacial changes in $\mathrm{CO}_{3}^{2-}$ (Yu et al., 2010, 2013).

The results confirm that the nutrient-burial feedback identified by Tschumi et al. (2011) should not be neglected (e.g. Sigman et al., 1998; Matsumoto et al., 2007; Chikamoto et al., 2008) when discussing long-term carbon cycle changes. This nutrient-burial feedback arising as marine biological productivity in the long run is limited by the
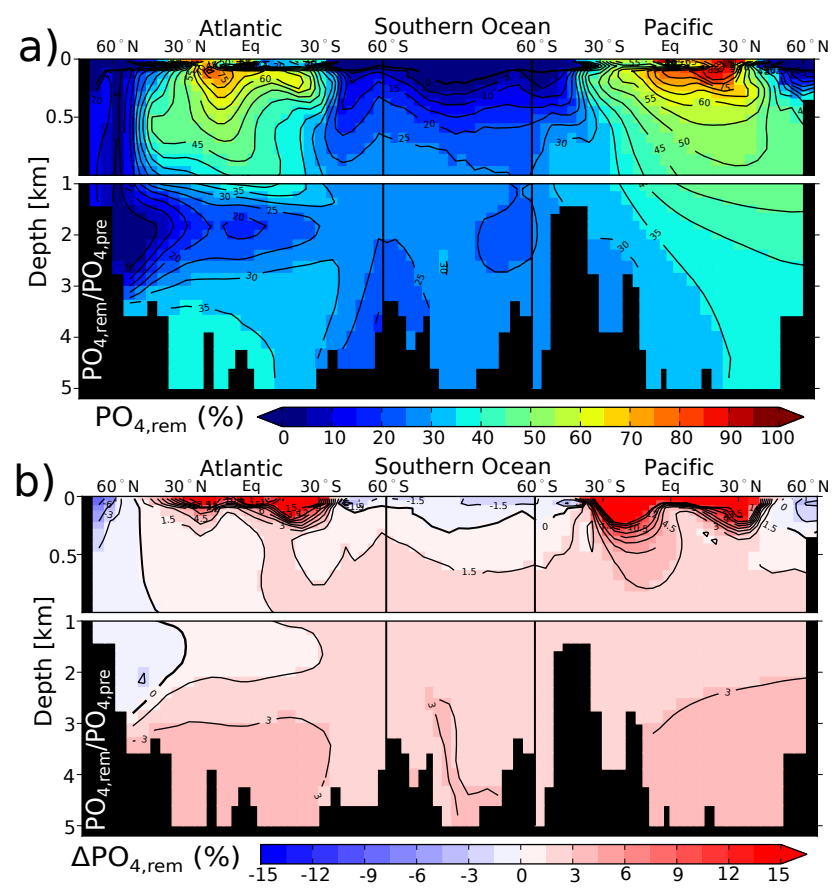

Figure 10. (a) Percentage fraction of remineralised : preformed nutrients in the control simulation. Remineralised nutrient concentration is estimated as $-\mathrm{AOU} / 170$, where $\mathrm{AOU}$ denotes the apparent oxygen utilisation as calculated as $\mathrm{O}_{2}-\mathrm{O}_{2 \text {,sat }}$ (b) Change in this fraction in a POM deepening experiment $\left(l_{\mathrm{POM}}: 250 \mathrm{~m} \rightarrow 275 \mathrm{~m}\right)$ in the open system.

riverine or aeolian input of nutrients into the ocean. The burial flux, not only of $\mathrm{CaCO}_{3}$ but also of POM, must relax to the input flux of tracers into the ocean. This nutrientburial feedback amplifies the initial response to a deepening of the POM remineralisation by a factor of between 3 and 7 in our model. There are small changes in $\Delta^{14} \mathrm{C}$ in the atmosphere and the ocean in our POM-deepening experiments. On the other hand, we find substantial changes in alkalinity, DIC, oxygen, and atmospheric $\mathrm{CO}_{2}$. This suggests that the relationship between $\Delta^{14} \mathrm{C}$ and DIC observed in the modern ocean (Sarnthein et al., 2013) may not always be applicable to infer changes in DIC from changes in $\Delta^{14} \mathrm{C}$.

We have shown that a change in the rate of organic matter degradation constitutes an important potential feedback for atmospheric $\mathrm{CO}_{2}$ to temperature change. Small changes in the remineralisation depth lead to surprisingly large changes in atmospheric $\mathrm{CO}_{2}$ and related tracers in particular over glacial-interglacial timescales. While the available proxy records do not support the conclusion that a deepening in the POM remineralisation depth played a dominant role in the $\mathrm{CO}_{2}$ increase during the last termination, the high sensitivity implies that subtle changes in the remineralisation depth on global to regional scales cannot be easily disregarded for the explanation of the long-term evolution of atmospheric $\mathrm{CO}_{2}$ and $\delta^{13} \mathrm{C}$, the distribution of nutrients, alkalinity, oxygen, carbonate ions or $\delta^{13} \mathrm{C}$ within the ocean, as well as for marine productivity, particle fluxes, and sedimentation. 


\section{Appendix A: Bern3D model update}

Recently, the physical core of the Bern3D ocean component underwent some major changes, leading to notable improvements (Fig. A1). Before this update, only horizontal grids with a latitudinal spacing proportional to the sine of the latitude were possible, such that the surface area of all gridboxes is equal. Based on this constraint, many equations were simplified in the original Bern3D model (Müller et al., 2006) (which in turn is based on the GOLDSTEIN model; Edwards and Marsh, 2005), as gridcell areas were omitted in the equations.

All equations were generalised to be used with arbitrary rectangular grids. Several horizontal grid configurations were tested in an early stage. A grid with $41 \times 40$ gridboxes in the horizontal featuring a higher latitudinal resolution in the Southern Ocean as well as an increased longitudinal resolution in the Atlantic has been chosen. The old and new grids are shown in Fig. A2. This particular $41 \times 40$ grid offers a good balance between computational efficiency and increased resolution in important locations. Although the number of boxes only modestly increased, the timestep $(\delta t)$ had to be decreased by a factor of two in order to maintain numerical stability.

In addition to the horizontal resolution, some minor changes were incorporated into the ocean, EBM and biogeochemical modules, as described in the following. As a result of a proper re-tuning of all model components, there is some notable improvement in the modelled ocean distribution of tracers, as illustrated in the Taylor diagram shown in Fig. A1. For a more detailed description and the present-day solution, see Roth (2013, Chap. 2).

\section{A1 Physical component}

The following changes in the physical part were made (parameters w.r.t. the $36 \times 36$ setup as described in Ritz et al., 2011a and updated in Ritz et al., 2011b):

- new grid with $41 \times 40$ gridboxes in the horizontal.

- Ocean:

- new parameter set (see Table A1)

- new time step: 96 time steps per year (instead of 48 time steps per year in the old version)

- max. isopycnal slope has been increased to prevent spatial oscillations of the tracer fields in the Southern Ocean

- shuffling convection is now applied for all tracers (instead of only to $T$ and $S$ ).

- Atmosphere:

- new parameter set (see Table A1)

- no Atlantic-to-Pacific freshwater correction flux

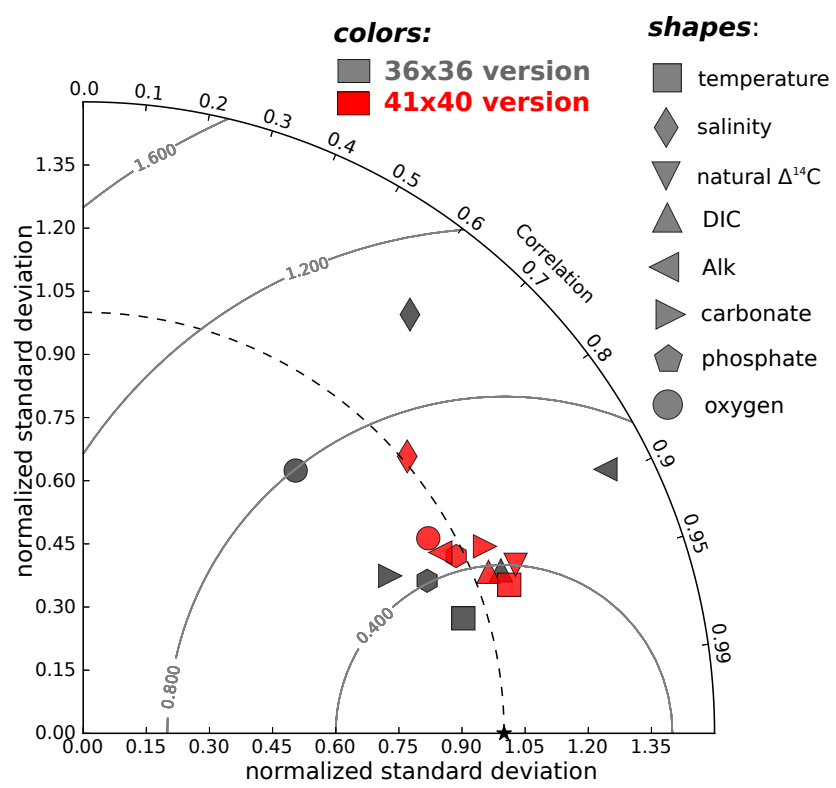

Figure A1. Taylor diagram for global, volume-weighted oceanic tracer distributions. Results from the previous $(36 \times 36)$ model version are shown by grey and results from the updated version $(41 \times 40)$ by red symbols.

- zonal resolved winds are now used for moisture and heat advection

- zonal eddy-diffusive transport of heat is now a function of latitude (see Table A1)

- moisture advection is now reduced by a scaling factor $\beta_{\text {moist }}=0.5$

- land albedo changes through snow are now taken into account by default. Changes in snow albedo calculated by the snow albedo parametrisation of Ritz et al. (2011b) are accounted for as anomalies to the fixed surface albedo. Minimum snow albedo is the MODIS ${ }^{1}$ land surface albedo from which the snow contribution has been removed

- air-sea momentum transfer (i.e. wind stress) is reduced by fractional sea-ice cover $\left(F_{\text {ice }}\right)$ by a factor of $\left(1-F_{\text {ice }}^{2}\right)$.

- Sea ice:

- sea ice is solved with a separate time-stepping: 10 steps per atmospheric time step

- sea ice advection is reduced to 0.3 times the surface ocean current for better consistency with observations.

\footnotetext{
${ }^{1}$ The Moderate Resolution Imaging Spectroradiometer.
} 
- Ice sheet:

- new ice-sheet parametrisation: Greenland and Antarctica are now assumed to have temporally constant ice-sheet cover. Due to this, the climate is no longer affected when ice sheets are activated at a present day state (albedo of Greenland and Antarctica remain at the values of the MODIS climatology)

- updated ice-sheet mask (Peltier, 2004).

In the $41 \times 40$ version, the key ocean parameters remained largely unchanged, with the exception of an ad hoc doubling of diapycnal diffusivity $\left(k_{\mathrm{D}}\right)$ from $10^{-5} \mathrm{~m}^{2} \mathrm{~s}^{-1}$ to $2 \times 10^{-5} \mathrm{~m}^{2} \mathrm{~s}^{-1}$. This change was motivated by the lowerthan-observed rates of anthropogenic $\mathrm{CO}_{2}$ uptake in the old model version (Gerber and Joos, 2013). With the new model, the cumulative uptake of $\mathrm{CO}_{2}$ from $\mathrm{AD} 1765$ to 2011 is $156 \mathrm{GtC}$, which compares well with observational estimates of $155 \pm 31 \mathrm{GtC}$ (Le Quéré et al., 2013).

\section{A2 Biogeochemical component}

The following changes in the biogeochemical component were made (parameters w.r.t. the $36 \times 36$ setup as described in Parekh et al., 2008, and Tschumi et al. 2008, 2011):
- Ocean biogeochemistry:

- new parameter set (see Table A2)

- new windspeed climatology (from NCEP instead of PO.DACC) for the gas exchange formulation

- new present-day dust input fields from Mahowald et al. (2006)

- virtual fluxes are now applied to all biogeochemical tracers.

- Sediment:

- new parameter set (see Table A2)

- Alk:P ratio for organic matter formation and remineralisation is set to -17 according to Paulmier et al. (2009)

- weathering input is now distributed along the coastline instead of the entire surface ocean

- organic matter denitrification disabled per default to avoid model drift. 
Table A1. Parameters in the ocean (OCN) and energy-balance atmosphere (EBM) modules that changed with respect to the parameters listed in Ritz et al. (2011a).

\begin{tabular}{|c|c|c|c|c|}
\hline Module & Parameter & New value & Units & Description \\
\hline OCN & $k_{\mathrm{D}}$ & $2 \times 10^{-5}$ & $\mathrm{~m}^{2} \mathrm{~s}^{-1}$ & Diapycnal diffusivity \\
\hline $\mathrm{OCN}$ & fwso & 0.07 & Sv & Weddell Sea freshwater removal \\
\hline $\mathrm{OCN}$ & $\mathrm{fw}_{\text {Atl-Pac }}$ & 0.0 & $\mathrm{~Sv}$ & Atlantic to Pacific freshwater flux correction \\
\hline $\mathrm{OCN}$ & $\mathrm{ss}_{\max }$ & 40 & - & Slope limitation of isopycnals \\
\hline EBM & $\varepsilon_{1}$ & 1.00 & - & Reference land emissivity \\
\hline EBM & $G_{\mathrm{cl}}$ & 0.219 & - & $\begin{array}{l}\text { Fraction of shortwave radiation that is reflected by the } \\
\text { atmosphere in the standard case for clear-sky conditions }\end{array}$ \\
\hline EBM & $G_{\mathrm{OV}}$ & 0.379 & - & $\begin{array}{l}\text { Fraction of shortwave radiation that is reflected by the } \\
\text { atmosphere in the standard case for overcast conditions }\end{array}$ \\
\hline EBM & $\lambda_{\text {rad }}$ & 0.641 & - & $\begin{array}{l}\text { Ratio between the total transmissivity in overcast and } \\
\text { clear-sky conditions for the standard cases }\end{array}$ \\
\hline EBM & $r_{\mathrm{h}, \text { precip }}$ & 0.85 & - & Relative humidity after precipitation \\
\hline EBM & $K_{\varphi}$ & $2.0 \times 10^{5}+\left(2.0 \times 10^{7}-2.0 \times 10^{5}\right) \times \cos ^{4} \vartheta$ & $\mathrm{m}^{2} \mathrm{~s}^{-1}$ & Zonal eddy diffusivity of heat \\
\hline EBM & $K_{\vartheta}$ & $1.2 \times 10^{6}+0.6 \times 10^{6} \frac{\vartheta+\pi / 2}{\pi}+2.5 \times 10^{6} \cos ^{2} \vartheta$ & $\mathrm{m}^{2} \mathrm{~s}^{-1}$ & Meridional eddy diffusivity of heat \\
\hline EBM & $\beta_{\text {moist }}$ & 0.5 & - & Scaling coefficient for moisture advection \\
\hline EBM & $\lambda_{\mathrm{lw} \text { rad }}$ & -0.71 & $\mathrm{~W} \mathrm{~m}^{-2} \mathrm{~K}^{-1}$ & Feedback parameter \\
\hline EBM & $K_{i}$ & $1.5 \times 10^{4}$ & $\mathrm{~m}^{2} \mathrm{~s}^{-1}$ & Sea-ice diffusion coefficient \\
\hline EBM & $\beta_{\text {ice }}$ & 0.3 & - & Scaling coefficient for sea-ice advection \\
\hline EBM & $\alpha_{\text {seaice }}$ & 0.65 & - & Sea-ice albedo \\
\hline EBM & $\alpha_{\text {icesheet }}$ & 0.7 & - & Ice-sheet albedo \\
\hline EBM & $\alpha_{\text {snow }}^{\max }$ & 0.75 & - & Maximum snow albedo \\
\hline EBM & $H_{0}$ & 0.05 & $\mathrm{~m}$ & Minimal ice thickness \\
\hline
\end{tabular}

Table A2. Overview of updated parameters in the $41 \times 40$ setup of the ocean biogeochemistry (BGC) and sediment (SED) modules w.r.t. Tschumi et al. (2011).

\begin{tabular}{|c|c|c|c|c|}
\hline Module & Parameter & New value & Units & Description \\
\hline BGC & $\mathcal{R}_{\mathrm{Alk}: \mathrm{P}}$ & -17 & - & Ratio Alk : P for photosynthesis/remineralisation \\
\hline BGC & Alk $_{\text {init }}$ & 2.429 & $\mathrm{~mol} \mathrm{~m}^{-3}$ & Initial Alk concentration \\
\hline BGC & $\sigma$ & 0.68 & - & DOM fraction of new production \\
\hline BGC & $M_{\mathrm{CaCO}_{3}}$ & 0.25 & - & Maximum $\mathrm{CaCO}_{3}$ production relative to $\mathrm{POM}$ \\
\hline BGC & $l_{\mathrm{CaCO}_{3}}$ & 2900 & $\mathrm{~m}$ & $\mathrm{CaCO}_{3}$ dissolution length scale \\
\hline BGC & $\alpha$ & 0.83 & - & Exponent for Martin curve (POM remineralisation) \\
\hline BGC & $\beta$ & 0.0018 & - & Fe solubility \\
\hline BGC & $L_{\text {tot }}$ & $1.2 \times 10^{-6}$ & $\mathrm{~mol} \mathrm{~m}^{-3}$ & Total ligand concentration \\
\hline SED & $\mathcal{R}_{\mathrm{Alk}: \mathrm{P}}$ & -17 & - & Redfield ratio Alk: $\mathrm{P}$ for organic matter \\
\hline SED & $F_{\text {clay }}$ & 0.8 & $\mathrm{~g} \mathrm{~m}^{-2} \mathrm{yr}^{-1}$ & Terrestrial clay flux \\
\hline SED & $r_{\text {oxy }}$ & 100 & $\mathrm{~L} \mathrm{~mol}^{-1} \mathrm{yr}^{-1}$ & Reactivity for $\mathrm{POC} / \mathrm{O}_{2}$ \\
\hline SED & $r_{\text {denit }}$ & 0 & $\mathrm{~L} \mathrm{~mol}^{-1} \mathrm{yr}^{-1}$ & Reactivity for $\mathrm{POC} / \mathrm{NO}_{3}$ (denitrification) \\
\hline
\end{tabular}



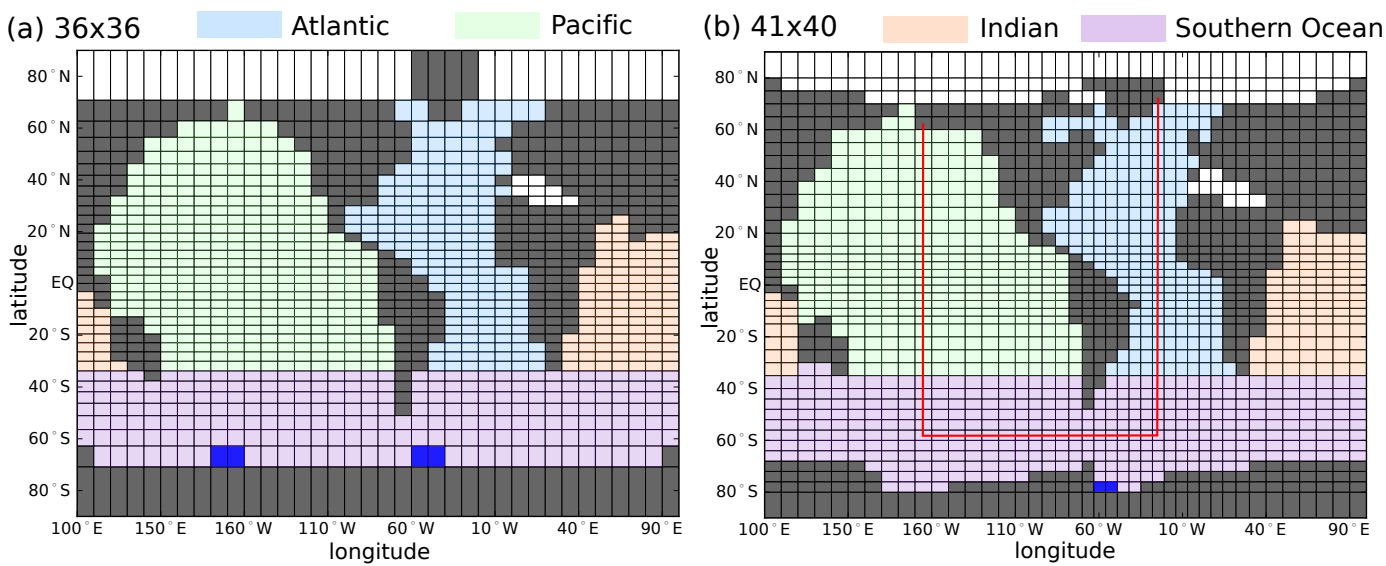

Figure A2. Comparison of the horizontal grid for the previous $(36 \times 36)(\mathbf{a})$ and updated $(41 \times 40)(\mathbf{b})$ versions of the Bern $3 \mathrm{D}$ ocean model. Both versions feature 32 depth layers. Latitudinal resolution near the Equator remained largely unchanged, while resolution was increased at the high latitudes. The ocean, atmosphere and sediment models share the same horizontal grid. The red line in (b) shows the path of the transect plot used in the main text. The light colours depict the definition of ocean basins as used to calculate depth gradients and zonal means. 
Acknowledgements. This work is supported by the European Commission through Seventh Framework Program (FP7) projects CARBOCHANGE (grant no. 264879) and Past4Future (grant no. 243908), and the Swiss National Science Foundation.

Edited by: C. Heinze

\section{References}

Anderson, L. D., Delaney, M. L. and Faul, K. L.: Carbon to phosphorus ratios in sediments: Implications for nutrient cycling, Global Biogeochem. Cy., 15, 65-79, doi:10.1029/2000gb001270, 2001.

Antonov, J. I., Seidov, D., Boyer, T. P., Locarnini, R. A., Mishonov, A. V., Garcia, H. E., Baranova, O. K., Zweng, M. M., and Johnson, D. R.: World Ocean Atlas 2009, Volume 2: Salinity, NOAA Atlas NESDIS 69, US Government Printing Office, Washington, D.C., 2010.

Archer, D., Winguth, A., Lea, D., and Mahowald, N.: What caused the glacial/interglacial atmospheric $p \mathrm{CO}_{2}$ cycles?, Rev. Geophys., 38, 159-189, doi:10.1029/1999RG000066, 2000.

Armstrong, R. A., Lee, C., Hedges, J. I., Honjo, S., and Wakeham, S. G.: A new, mechanistic model for organic carbon fluxes in the ocean based on the quantitative association of POC with ballast minerals, Deep-Sea Res. Pt. II, 49, 219-236, doi:10.1016/S0967-0645(01)00101-1, 2002.

Armstrong, R. A., Peterson, M. L., Lee, C., and Wakeham, S. G.: Settling velocity spectra and the ballast ratio hypothesis, DeepSea Res. Pt. II, 56, 1470-1478, doi:10.1016/j.dsr2.2008.11.032, 2009.

Arora, V. K., Boer, G. J., Friedlingstein, P., Eby, M., Jones, C. D., Christian, J. R., Bonan, G., Bopp, L., Brovkin, V., Cadule, P., Hajima, T., Ilyina, T., Lindsay, K., Tjiputra, J. F., and $\mathrm{Wu}$, T.: Carbon-concentration and carbon-climate feedbacks in CMIP5 Earth System Models, J. Climate, 26, 5289-5314, doi:10.1175/JCLI-D-12-00494.1, 2013.

Barrett, P. M., Resing, J. A., Buck, N. J., Feely, R. A., Bullister, J. L., Buck, C. S., and Landing, W. M.: Calcium carbonate dissolution in the upper $1000 \mathrm{~m}$ of the eastern North Atlantic, Global Biogeochem. Cy., 28, 386-397, doi:10.1002/2013GB004619, 2014.

Bendtsen, J., Lundsgaard, C., Middelboe, M., and Archer, D.: Influence of bacterial uptake on deep-ocean dissolved organic carbon, Global Biogeochem. Cy., 16, 1127, doi:10.1029/2002GB001947, 2002.

Berelson, W. M., Balch, W. M., Najjar, R., Feely, R. A., Sabine, C., and Lee, K.: Relating estimates of $\mathrm{CaCO}_{3}$ production, export, and dissolution in the water column to measurements of $\mathrm{CaCO}_{3}$ rain into sediment traps and dissolution on the sea floor: a revised global carbonate budget, Global Biogeochem. Cy., 21, GB1024, doi:10.1029/2006GB002803, 2007.

Bouttes, N., Paillard, D., and Roche, D. M.: Impact of brine-induced stratification on the glacial carbon cycle, Clim. Past, 6, 575-589, doi:10.5194/cp-6-575-2010, 2010.

Boyle, E. A.: Vertical oceanic nutrient fractionation and glacial/interglacial $\mathrm{CO}_{2}$ cycles, Nature, 331, 55-56, doi:10.1038/331055a0, 1988.

Bradtmiller, L., Anderson, R., Sachs, J., and Fleisher, M.: A deeper respired carbon pool in the glacial equato- rial Pacific Ocean, Earth Planet. Sc. Lett., 299, 417-425, doi:10.1016/j.eps1.2010.09.022, 2010.

Burdige, D. A.: Preservation of organic matter in marine sediments: Controls, mechanisms, and an imbalance in sediment organic carbon budgets?, Chem. Rev., 107, 467-485, doi:10.1021/cr050347q, 2007.

Chikamoto, M. O., Matsumoto, K., and Ridgwell, A.: Response of deep-sea $\mathrm{CaCO}_{3}$ sedimentation to Atlantic meridional overturning circulation shutdown, J. Geophys. Res., 113, G03017, doi:10.1029/2007JG000669, 2008.

Chikamoto, M. O., Abe-Ouchi, A., Oka, A., and Smith, S. L.: Temperature-induced marine export production during glacial period, Geophys. Res. Lett., 39, L21601, doi:10.1029/2012GL053828, 2012.

Colbourn, G., Ridgwell, A., and Lenton, T. M.: The Rock Geochemical Model (RokGeM) v0.9, Geosci. Model Dev., 6, 1543-1573, doi:10.5194/gmd-6-1543-2013, 2013.

Delaney, M. L.: Phosphorus accumulation in marine sediments and the oceanic phosphorus cycle, Global Biogeochem. Cy., 12, 563572, doi:10.1029/98gb02263, 1998.

Doney, S. C., Lindsay, K., Fung, I., and John, J.: Natural variability in a stable, 1000-yr global coupled climate-carbon cycle simulation, J. Climate, 19, 3033-3054, doi:10.1175/JCLI3783.1, 2006.

Edwards, N. R. and Marsh, R.: Uncertainties due to transportparameter sensitivity in an efficient 3-D ocean-climate model, Clim. Dynam., 24, 415-433, doi:10.1007/s00382-004-0508-8, 2005.

Feely, R., Sabine, C., Lee, K., Berelson, W., Kleypas, J., Fabry, V., and Millero, F.: Impact of anthropogenic $\mathrm{CO}_{2}$ on the $\mathrm{CaCO}_{3}$ system in the oceans, Science, 305, 362-366, doi:10.1126/science.1097329, 2004.

Fischer, H., Schmitt, J., Lüthi, D., Stocker, T. F., Tschumi, T., Parekh, P., Joos, F., Köhler, P., Völker, C., Gersonde, R., Barbante, C., Le Floch, M., Raynaud, D., and Wolff, E. W.: The role of Southern Ocean processes on orbital and millenial $\mathrm{CO}_{2}$ variations - a synthesis, Quaternary Sci. Rev., 29, 193-205, doi:10.1016/j.quascirev.2009.06.007, 2010.

Freeman, K. H. and Hayes, J. M.: Fractionation of carbon isotopes by phytoplankton and estimates of ancient $\mathrm{CO}_{2}$ levels, Global Biogeochem. Cy., 6, 185-198, doi:10.1029/92GB00190, 1992.

Gangst $\varnothing$, R., Joos, F., and Gehlen, M.: Sensitivity of pelagic calcification to ocean acidification, Biogeosciences, 8, 433-458, doi:10.5194/bg-8-433-2011, 2011.

Gehlen, M., Bopp, L., Emprin, N., Aumont, O., Heinze, C., and Ragueneau, O.: Reconciling surface ocean productivity, export fluxes and sediment composition in a global biogeochemical ocean model, Biogeosciences, 3, 521-537, doi:10.5194/bg-3521-2006, 2006.

Gerber, M. and Joos, F.: An Ensemble Kalman Filter multi-tracer assimilation: determining uncertain ocean model parameters for improved climate-carbon cycle projections, Ocean Model., 64, 29-45, doi:10.1016/j.ocemod.2012.12.012, 2013.

Griffies, S. M.: The Gent-McWilliams skew flux, J. Phys. Oceanogr., 28, 831-841, doi:10.1175/15200485(1998)028<0831:TGMSF>2.0.CO;2, 1998.

Hedges, J. I. and Keil, R. G.: Sedimentary organic matter preservation: an assessment and speculative synthesis, Mar. Chem., 49, 81-115, doi:10.1016/0304-4203(95)00008-F, 1995. 
Heinze, C., Maier-Reimer, E., Winguth, A. M. E., and Archer, D.: A global oceanic sediment model for long-term climate studies, Global Biogeochem. Cy., 13, 221-250, 1999.

Hibler, W.: A dynamic thermodynamic sea ice model, J. Phys. Oceanogr., 9, 815-846, doi:10.1175/15200485(1979)009<0815:ADTSIM>2.0.CO;2, 1979.

Huybers, P. and Langmuir, C.: Feedback between deglaciation, volcanism, and atmospheric $\mathrm{CO}_{2}$, Earth Planet. Sc. Lett., 286, 479491, doi:10.1016/j.epsl.2009.07.014, 2009.

Jaccard, S. L. and Galbraith, E. D.: Large climate-driven changes of oceanic oxygen concentrations during the last deglaciation, Nat. Geosci., 5, 151-156, doi:10.1038/ngeo1352, 2011.

Jaccard, S. L., Galbraith, E., Sigman, D., Haug, G., Francois, R., Pedersen, T., Dulski, P., and Thierstein, H.: Subarctic Pacific evidence for a glacial deepening of the oceanic respired carbon pool, Earth Planet. Sc. Lett., 277, 156-165, doi:10.1016/j.epsl.2008.10.017, 2009.

Jin, X., Gruber, N., Dunne, J. P., Sarmiento, J. L., and Armstrong, R. A.: Diagnosing the contribution of phytoplankton functional groups to the production and export of particulate organic carbon, $\mathrm{CaCO}_{3}$, and opal from global nutrient and alkalinity distributions, Global Biogeochem. Cy., 20, GB2015, doi:10.1029/2005GB002532, 2006.

Joos, F., Plattner, G.-K., Stocker, T. F., Marchal, O., and Schmittner, A.: Global warming and marine carbon cycle feedbacks on future atmospheric $\mathrm{CO}_{2}$, Science, 284, 464-467, doi:10.1126/science.284.5413.464, 1999.

Kalnay, E., Kanamitsu, M., Kistler, R., Collins, W., Deaven, D., Gandin, L., Iredell, M., Saha, S., White, G., Woollen, J., Zhu, Y., Chelliah, M., Ebisuzaki, W., Higgins, W., Janowiak, J., Mo, K., Ropelewski, C., Wang, J., Leetmaa, A., Reynolds, R., Jenne, R., and Joseph, D.: The NCEP/NCAR 40-year reanalysis project, B. Am. Meteorol. Soc., 77, 437-471, doi:10.1175/15200477(1996)077<0437:TNYRP>2.0.CO;2, 1996.

Key, R. M., Kozyr, A., Sabine, C. L., Lee, K., Wanninkhof, R., Bullister, J. L., Feely, R. A., Millero, F. J., Mordy, C., and Peng, T.-H.: A global ocean carbon climatology: results from Global Data Analysis Project (GLODAP), Global Biogeochem. Cy., 18, GB4031, doi:10.1029/2004GB002247, 2004.

Kwon, E. Y., Primeau, F., and Sarmiento, J. L.: The impact of remineralization depth on the air-sea carbon balance, Nat. Geosci., 2, 630-635, doi:10.1038/ngeo612, 2009.

Le Quéré, C., Andres, R. J., Boden, T., Conway, T., Houghton, R. A., House, J. I., Marland, G., Peters, G. P., van der Werf, G. R., Ahlström, A., Andrew, R. M., Bopp, L., Canadell, J. G., Ciais, P., Doney, S. C., Enright, C., Friedlingstein, P., Huntingford, C., Jain, A. K., Jourdain, C., Kato, E., Keeling, R. F., Klein Goldewijk, K., Levis, S., Levy, P., Lomas, M., Poulter, B., Raupach, M. R., Schwinger, J., Sitch, S., Stocker, B. D., Viovy, N., Zaehle, S., and Zeng, N.: The global carbon budget 1959-2011, Earth Syst. Sci. Data, 5, 165-185, doi:10.5194/essd-5-165-2013, 2013.

Locarnini, R. A., Mishonov, A. V., Antonov, J. I., Boyer, T. P., Garcia, H. E., Baranova, O. K., Zweng, M. M., and Johnson, D. R.: World Ocean Atlas 2009, Volume 1: Temperature, NOAA Atlas NESDIS 68, US Government Printing Office, Washington, D.C., 2010.

Lüthi, D., Le Floch, M., Bereiter, B., Blunier, T., Barnola, J.-M., Siegenthaler, U., Raynaud, D., Jouzel, J., Fischer, H., Kawamura, K., and Stocker, T. F.: High-resolution carbon dioxide con- centration record 650,000-800,000 years before present, Nature, 453, 379-382, doi:10.1038/nature06949, 2008

Mahowald, N. M., Muhs, D. R., Levis, S., Rasch, P. J., Yoshioka, M., Zender, C. S., and Luo, C.: Change in atmospheric mineral aerosols in response to climate: last glacial period, preindustrial, modern, and doubled carbon dioxide climates, J. Geophys. Res., 111, D10202, doi:10.1029/2005JD006653, 2006.

Martin, J. H., Knauer, G. A., Karl, D. M., and Broenkow, W.: VERTEX: carbon cycling in the northeast Pacific, Deep-Sea Res. Pt. I, 34, 267-285, doi:10.1016/0198-0149(87)90086-0, 1987.

Matsumoto, K.: Biology-mediated temperature control on atmospheric $p \mathrm{CO}_{2}$ and ocean biogeochemistry, Geophys. Res. Lett. 34, L20605, doi:10.1029/2007GL031301, 2007.

Matsumoto, K., Hashioka, T., and Yamanaka, Y.: Effect of temperature-dependent organic carbon decay on atmospheric $p \mathrm{CO}_{2}$, J. Geophys. Res., 112, G02007, doi:10.1029/2006JG000187, 2007.

Menviel, L., Joos, F., and Ritz, S.: Simulating atmospheric $\mathrm{CO}_{2},{ }^{13} \mathrm{C}$ and the marine carbon cycle during the Last Glacial-Interglacial cycle: possible role for a deepening of the mean remineralization depth and an increase in the oceanic nutrient inventory, Quaternary Sci. Rev., 56, 46-68, doi:10.1016/j.quascirev.2012.09.012, 2012.

Middleburg, J. J., Vlug, T., and Vandernat, F. J. W. A.: Organicmatter mineralization in marine systems, Global Planet. Change, 8, 47-58, doi:10.1016/0921-8181(93)90062-S, 1993.

Milliman, J. and Droxler, A.: Neritic and pelagic carbonate sedimentation in the marine environment: ignorance is not bliss, Geol. Rundsch., 85, 496-504, doi:10.1007/BF02369004, 1996.

Mucci, A.: The solubility of calcite and aragonite in seawater at various salinities, temperatures, and one atmosphere total pressure, Am. J. Sci., 283, 780-799, 1983.

Müller, S. A., Joos, F., Edwards, N. R., and Stocker, T. F.: Water mass distribution and ventilation time scales in a cost-efficient, three-dimensional ocean model, J. Climate, 19, 5479-5499, doi:10.1175/JCLI3911.1, 2006.

Müller, S. A., Joos, F., Edwards, N. R., and Stocker, T. F.: Modeled natural and excess radiocarbon: sensitivities to the gas exchange formulation and ocean transport strength, Global Biogeochem. Cy., 22, GB3011, doi:10.1029/2007GB003065, 2008.

Munhoven, G.: Glacial-interglacial changes of continental weathering: estimates of the related $\mathrm{CO}_{2}$ and $\mathrm{HCO}_{3}^{-}$flux variations and their uncertainties, Global Planet. Change, 33, 155-176, doi:10.1016/s0921-8181(02)00068-1, 2002.

Najjar, R. G., Orr, J., Sabine, C. L., and Joos, F.: Biotic-HOWTO, Internal OCMIP Report, Tech. rep., LSCE/CEA Saclay, Gif-surYvette, France, 1999.

Oka, A., Abe-Ouchi, A., Chikamoto, M. O., and Ide, T.: Mechanisms controlling export production at the LGM: effects of changes in oceanic physical fields and atmospheric dust deposition, Global Biogeochem. Cy., 25, GB2009, doi:10.1029/2009GB003628, 2011.

Orr, J. and Najjar, R. G.: Abiotic-HOWTO, Internal OCMIP Report, Tech. rep., LSCE/CEA Saclay, Gif-sur-Yvette, France, 1999.

Parekh, P., Joos, F., and Müller, S. A.: A modeling assessment of the interplay between aeolian iron fluxes and ironbinding ligands in controlling carbon dioxide fluctuations during Antarctic warm events, Paleoceanography, 23, PA4202, doi:10.1029/2007PA001531, 2008 . 
Paulmier, A., Kriest, I., and Oschlies, A.: Stoichiometries of remineralisation and denitrification in global biogeochemical ocean models, Biogeosciences, 6, 923-935, doi:10.5194/bg-6923-2009, 2009.

Peltier, W. R.: Global glacial isostasy and the surface of the Ice-Age Earth: the ICE-5G (VM2) model and GRACE, Annu. Rev. Earth Pl. Sc., 32, 111-149, doi:10.1146/annurev.earth.32.082503.144359, 2004.

Petit, J. R., Jouzel, J., Raynaud, D., Barkov, N. I., Barnola, J.-M., Basile, I., Bender, M., Chappellaz, J., Davis, M., Delaygue, G., Delmotte, M., Kotlyakov, V. M., Legrand, M., Lipenkov, V. Y., Lorius, C., Pepin, L., Ritz, C., Saltzman, E., and Stievenard, M.: Climate and atmospheric history of the past 420,000 years from the Vostok ice core, Antarctica, Nature, 399, 429-436, doi:10.1038/20859, 1999.

Plattner, G.-K., Knutti, R., Joos, F., Stocker, T. F., von Bloh, W., Brovkin, V., Cameron, D., Driesschaert, E., Dutkiewiz, S., Eby, M., Edwards, N. R., Fichefet, T., Hargreaves, J. C., Jones, C. D., Loutre, M. F., Matthews, H. D., Mouchet, A., Müller, S. A., Nawrath, S., Price, A., Sokolov, A., Strassmann, K. M., and Weaver, A. J.: Long-term climate commitments projected with climate-carbon cycle models, J. Climate, 21, 2721-2751, doi:10.1175/2007JCLI1905.1, 2008.

Regnier, P., Friedlingstein, P., Ciais, P., Mackenzie, F. T., Gruber, N., Janssens, I., Laruelle, G. G., Lauerwald, R., Luyssaert, S., Andersson, A. J., Arndt, S., Arnosti, C., Borges, A. V., Dale, A. W., Gallego-Sala, A., Goddéris, Y., Goossens, N., Hartmann, J., Heinze, C., Ilyina, T., Joos, F., LaRowe, D. E., Leifeld, J., Meysman, F. J. R., Munhoven, G., Raymond, P. A., Spahni, R., Suntharalingam, P., and Thullner, M.: Global Carbon budget and its anthropogenic perturbation in the land-ocean aquatic continuum, Nat. Geosci., 6, 597-607, doi:10.1038/ngeo1830, doi:10.1038/ngeo1830, 2013.

Ritz, S. P., Stocker, T. F., and Joos, F.: A coupled dynamical oceanenergy balance atmosphere model for paleoclimate studies, J. Climate, 24, 349-375, doi:10.1175/2010JCLI3351.1, 2011a.

Ritz, S. P., Stocker, T. F., and Severinghaus, J. P.: Noble gases as proxies of mean ocean temperature: sensitivity studies using a climate model of reduced complexity, Quaternary Sci. Rev., 30, 3728-3741, doi:10.1016/j.quascirev.2011.09.021, 2011b.

Roth, R.: Modeling forcings and responses in the global carbon cycle-climate system: past, present and future, Ph.D. thesis, University of Bern, Bern, 2013.

Roth, R. and Joos, F.: Model limits on the role of volcanic carbon emissions in regulating glacial-interglacial $\mathrm{CO}_{2}$ variations, Earth Planet. Sc. Lett., 329-330, 141-149, doi:10.1016/j.epsl.2012.02.019, 2012.

Sarmiento, J. L. and Gruber, N.: Ocean Biogeochemical Dynamics, Princeton University Press, Princeton, Oxford, 2006.

Sarnthein, M., Schneider, B., and Grootes, P. M.: Peak glacial ${ }^{14} \mathrm{C}$ ventilation ages suggest major draw-down of carbon into the abyssal ocean, Clim. Past, 9, 2595-2614, doi:10.5194/cp-92595-2013, 2013.

Schneider, B., Bopp, L., and Gehlen, M.: Assessing the sensitivity of modeled air-sea $\mathrm{CO}_{2}$ exchange to the remineralization depth of particulate organic and inorganic carbon, Global Biogeochem. Cy., 22, GB3021, doi:10.1029/2007GB003100, 2008.
Segschneider, J. and Bendtsen, J.: Temperature-dependent remineralization in a warming ocean increases surface $p \mathrm{CO}_{2}$ through changes in marine ecosystem composition, Global Biogeochem. Cy., 27, GB004684, doi:10.1002/2013GB004684, 2013.

Semtner, A. J.: A model for the thermodynamic growth of sea ice in numerical investigations of climate, J. Phys. Oceanogr., 6, 379-389, doi:10.1175/15200485(1976)006<0379:AMFTTG>2.0.CO;2, 1976.

Siegenthaler, U. and Wenk, Th.: Rapid atmospheric $\mathrm{CO}_{2}$ variations and ocean circulation, Nature, 308, 624-626, doi:10.1038/308624a0, 1984.

Siegenthaler, U., Stocker, T. F., Monnin, E., Lüthi, D., Schwander, J., Stauffer, B., Raynaud, D., Barnola, J.-M., Fischer, H., Masson-Delmotte, V., and Jouzel, J.: Stable carbon cycleclimate relationship during the Late Pleistocene, Science, 310, 1313-1317, doi:10.1126/science.1120130, 2005.

Sigman, D. M. and Boyle, E. A.: Glacial/interglacial variations in atmospheric carbon dioxide, Nature, 407, 859-869, doi:10.1038/35038000, 2000.

Sigman, D. M., McCorkle, D. C., and Martin, W. R.: The calcite lysocline as a constraint on glacial/interglacial low-latitude production changes, Global Biogeochem. Cy., 12, 409-427, doi:10.1029/98GB01184, 1998.

Sigman, D. M., Hain, M. P., and Haug, G. H.: The polar ocean and glacial cycles in atmospheric $\mathrm{CO}_{2}$ concentration, Nature, 466, 47-55, doi:10.1038/nature09149, 2010.

Steinacher, M., Joos, F., Frölicher, T. L., Bopp, L., Cadule, P., Cocco, V., Doney, S. C., Gehlen, M., Lindsay, K., Moore, J. K., Schneider, B., and Segschneider, J.: Projected 21st century decrease in marine productivity: a multi-model analysis, Biogeosciences, 7, 979-1005, doi:10.5194/bg-7-979-2010, 2010.

Taucher, J., Bach, L., Riebesell, U., and Oschlies, A.: The viscosity effect on marine particle flux - a climate relevant feedback mechanism, Global Biogeochem. Cy., 28, 415-422, doi:10.1002/2013GB004728, 2014.

Thompson, S. L. and Warren, S. G.: Parameterization of outgoing infrared radiation derived from detailed radiative calculations, J. Atmos. Sci., 39, 2667-2680, 1982.

Tréguer, P., Nelson, D. M., Van Bennekom, A. J., DeMaster, D. J., Leynaert, A., and Quéguiner, B.: The silica balance in the World Ocean: a reestimate, Science, 268, 375-379, doi:10.1126/science.268.5209.375, 1995.

Tschumi, T., Joos, F., and Parekh, P.: How important are Southern Hemisphere wind changes for low glacial carbon dioxide? A model study, Paleoceanography, 23, PA4208, doi:10.1029/2008PA001592, 2008.

Tschumi, T., Joos, F., Gehlen, M., and Heinze, C.: Deep ocean ventilation, carbon isotopes, marine sedimentation and the deglacial $\mathrm{CO}_{2}$ rise, Clim. Past, 7, 771-800, doi:10.5194/cp-7-771-2011, 2011.

Völker, C. and Köhler, P.: Responses of ocean circulation and carbon cycle to changes in the position of the Southern Hemisphere westerlies at Last Glacial Maximum, Paleoceanography, 28, 726-739, doi:10.1002/2013PA002556, 2013.

Wallmann, K., Pinero, E., Burwicz, E., Haeckel, M., Hensen, C. A., Dale, A., and Ruepke, L.: The global inventory of methane hydrate in marine sediments: A theoretical approach, Energies, 5, 2449-2498, doi:10.3390/en5072449, 2012. 
Watson, A. and Garabato, A.: The role of Southern Ocean mixing and upwelling in glacial-interglacial atmospheric $\mathrm{CO}_{2}$ change, Tellus B, 58, 73-87, doi:10.1111/j.1600-0889.2005.00167.x, 2006.

Weaver, A. J., Eby, M., Wiebe, E. C., Bitz, C. M., Duffy, P. B., Ewen, T. L., Fanning, A. F., Holland, M. M., MacFadyen, A., Wang, H. X., and Yoshimori, M.: The UVic Earth System Climate Model: model description, climatology, and applications to past, present and future climates, Atmos. Ocean, 39, 361-428, doi:10.1080/07055900.2001.9649686, 2001.
Yu, J., Broecker, W. S., Elderfield, H., Jin, Z., McManus, J., and Zhang, F.: Loss of carbon from the deep sea since the Last Glacial Maximum, Science, 330, 1084-1087, doi:10.1126/science.1193221, 2010.

Yu, J., Anderson, R. F., Jin, Z., Rae, J. W., Opdyke, B. N., and Eggins, S. M.: Responses of the deep ocean carbonate system to carbon reorganization during the last glacial-interglacial cycle, Quaternary Sci. Rev., 76, 39-52, doi:10.1016/j.quascirev.2013.06.020, 2013. 